\title{
Rethinking Measurement of Pay Disparity and its Relation to Firm Performance
}

\section{Citation}

Rouen, Ethan. "Rethinking Measurement of Pay Disparity and its Relation to Firm Performance." Harvard Business School Working Paper, No. 18-007, July 2017.

\section{Permanent link}

http://nrs.harvard.edu/urn-3:HUL.InstRepos:33468916

\section{Terms of Use}

This article was downloaded from Harvard University's DASH repository, and is made available under the terms and conditions applicable to Open Access Policy Articles, as set forth at http:// nrs.harvard.edu/urn-3:HUL.InstRepos:dash.current.terms-of-use\#OAP

\section{Share Your Story}

The Harvard community has made this article openly available.

Please share how this access benefits you. Submit a story.

\section{Accessibility}




\section{Rethinking Measurement of Pay Disparity and its Relation to Firm Performance}

Ethan Rouen

Working Paper 18-007 


\section{Rethinking Measurement of Pay Disparity and its Relation to Firm Performance}

Ethan Rouen

Harvard Business School

Working Paper 18-007 


\title{
Rethinking Measurement of Pay Disparity and its Relation to Firm Performance*
}

\author{
Ethan Rouen \\ Harvard Business School \\ erouen@hbs.edu
}

July 2017

*Disclaimer: This research was conducted with restricted access to Bureau of Labor Statistics (BLS) data. The views expressed here do not necessarily reflect the views of the BLS or the U.S. Government.

I am grateful for the support of my dissertation committee, Dan Amiram, Fabrizio Ferri (co-chair), Trevor Harris (cochair), Shiva Rajgopal, and Nachum Sicherman. Bureau of Labor Statistics employees Jessica Helfand, Michael LoBue, and Michael Soloy provided vital assistance with data. I benefited from the comments of Rob Brown, Elizabeth Handwerker, Mark Lowenstein, Ric Wise and workshop participants at Baruch College, Boston College, the Bureau of Labor Statistics Office of Employment and Unemployment Statistics, Columbia Business School, Emory University, Georgetown University, Harvard Business School, Indiana University, the Ohio State University, Rochester University, Stanford University, the University of California-Los Angeles, the University of Colorado, the University of Illinois-Chicago, the University of Michigan, the University of Minnesota, the University of North Carolina, and Yale School of Management. I also am thankful for financial support from the Deloitte Foundation, the W. Edwards Deming Center, the Institute of Management Accountants Research Foundation, and the Paul and Sandra Montrone Doctoral Fellowship. 


\title{
Rethinking Measurement of Pay Disparity and its Relation to Firm Performance
}

\begin{abstract}
I develop measures of firm-level pay disparity and examine their relation to firm accounting performance. Using comprehensive compensation data for a large sample of firms, I find no statistically significant relation between the ratio of CEO-to-mean employee compensation and performance. I next create empirical models that allow me to separate the components of CEO and employee compensation explained by economic factors from those that are not, and use these models to estimate explained and unexplained pay disparity. After validating my estimate of unexplained pay disparity as a proxy for pay fairness, I find robust evidence of a negative (positive) relation between unexplained (explained) pay disparity and future firm performance. Additional tests show that the negative relation between unexplained disparity and firm performance is driven by firms where both the CEO is overpaid and employees are underpaid, and is more pronounced for firms with weak corporate governance and high employee turnover.
\end{abstract}

Keywords: disclosure; CEO pay ratio; pay disparity; corporate culture; compensation

JEL Classifications: G32, G35, J31, M12, M14, M52, 


\section{Rethinking Measurement of Pay Disparity and its Relation to Firm Performance}

\section{Introduction}

In this paper, I develop measures of firm-level pay disparity, focusing on the ratio of CEO pay to average employee pay, and investigate how these measures relate to subsequent firm performance. The motivation for this examination is twofold. First, evidence of growing income inequality has led to greater interest in understanding firm-level pay disparity (viewed as a manifestation of, or, as some allege, a cause of income inequality) and its effect on firm performance. So far, the extensive literature on the relation between pay disparity and firm performance has yielded mixed results, even in near-identical settings (Gupta, Conroy, and Delery 2012). ${ }^{1}$ Studies documenting a positive relation often interpret it as consistent with the predictions of Tournament Theory, which posits that greater pay disparity increases the value of a promotion, leading to increased effort and better results (Lazear and Rosen 1981). Studies documenting a negative relation frequently present it as evidence in support of Equity Theory: Pay disparity will cause resentment among lower-level employees, leading them to take actions, such as shirking or quitting, that are detrimental to firm performance (Akerlof and Yellen 1990).

I argue that a potential reason for the inconsistent results is that many studies do not take into account how $\mathrm{CEO}$ and employee compensation are determined and therefore ignore the reasons for pay disparity. In interpreting pay disparity, researchers risk conflating income inequality - the difference in compensation between groups — and income inequity, or the notion that these differences are unfair or perceived as such (Trevor, Reilly, and Gerhart 2012). Compensation based on measurable attributes related to factors such as performance and labor

\footnotetext{
${ }^{1}$ For example, corporate pay disparity among managers and executives has been shown to be both positively (Main, O'Reilly, and Wade 1993; Lee, Lev, and Yeo 2008; Kale, Reis, and Venkateswaran 2009) and negatively (Bebchuk, Cremers, and Peyer 2011) related to accounting performance and firm value.
} 
market characteristics creates pay disparity but may motivate employees to perform better - as suggested by Tournament Theory — without necessarily creating a perception of income inequity. This is because, presumably, compensation decisions would be viewed as fair reflections of skill and effort. In contrast, pay disparity created by factors unrelated to economics, such as the unfair distribution of rents or favoritism, may create feelings of resentment, leading to actions that are detrimental to the firm, consistent with Equity Theory. To the extent that unadjusted pay disparity reflects both economic and non-economic factors, it becomes difficult to interpret any relation between disparity and performance, and to test the underlying theories. As detailed below, in this study I attempt to empirically separate the portion of disparity reflecting economic factors and the portion due to unidentified factors, and examine their differing effects on firm performance.

The second motivation for my examination of pay disparity is the recent adoption of the Securities and Exchange Commission's (SEC) rule mandating disclosure of the ratio of the CEO's compensation to median employee pay starting in 2018. The SEC has stated that comparability of CEO pay ratios is hampered by the discretion given to firms in identifying the median employee (e.g., how to treat foreign workers) (SEC 2015). I argue that a more fundamental problem is that CEO pay ratios are not directly comparable, even within the same industry, unless they are properly adjusted to reflect the economic determinants of both the numerator, CEO pay, and the denominator, employee pay. While there is an extensive literature on the determinants of CEO pay, less is known about the determinants of employee pay. As shown in this study, there is significant variation in the "denominator" of these ratios and such variation reflects important economic factors. For example, Apple is likely to have a pay ratio that is much higher than any other firm in its industry because of its many retail stores, a factor that lowers its average employee pay due to a higher fraction of retail employees (who command lower pay in the labor market) 
relative to better-paid engineers. Thus, for the SEC disclosure to be informative, it is important to separate economic and non-economic factors giving rise to differences in CEO pay ratios. ${ }^{2}$

One significant challenge to attempting this parsing of compensation is the unavailability of data related to non-executive compensation and workforce composition. To overcome this challenge and examine the relation between (different sources of) pay disparity and firm performance, I obtain detailed confidential establishment-level annual data provided by the U.S. Bureau of Labor Statistics (BLS) for a large sample of firms in the S\&P 1,500 from 2006 to 2013. These data include both total employee compensation and a series of establishment-level variables related to a firm's operating environment and potentially affecting employee pay (e.g., the composition of the workforce). ${ }^{3}$ I aggregate the employee compensation data to estimate mean employee pay at the firm level and compute the ratio of CEO compensation to mean employee compensation (the Simple Pay Ratio, or SPR, going forward). Using these BLS data, I next construct an empirical model predicting the level of mean employee pay (for a given establishment) as a function of establishment, local macroeconomic, and firm variables. This model explains $61 \%$ of establishment-level mean employee pay. I aggregate the predicted employee pay across all establishments at a given firm to estimate the explained portion of employee pay at the firm-level. ${ }^{4}$ Similarly, following prior studies on executive pay, I estimate CEO compensation as a function of firm, $\mathrm{CEO}$, and industry characteristics to obtain the explained portion of CEO pay (the model explains $56 \%$ of CEO pay). I define the ratio of explained CEO

\footnotetext{
${ }^{2}$ It is not entirely clear whether the new pay ratio disclosure is supposed to provide better information about CEO pay by providing a relative benchmark via median employee pay to help investors identify "excessive" CEO pay, or about firm-level pay disparity and thus pay fairness (Menendez 2011; SEC 2013). The adjustments to pay disparity proposed in this study are relevant in either case.

${ }^{3}$ BLS compensation data are measured at the establishment level. An establishment is a single physical business location. For example, each Starbucks store is an establishment, as is Starbucks headquarters.

${ }^{4}$ Consistent with the labor economics literature, I use the term "explained" to describe the component of compensation that is predicted by regression models.
} 
pay to explained employee pay as the Economic Pay Ratio, or EPR (i.e., the pay ratio that we would expect to observe based on the economic factors affecting CEO pay and those affecting employee pay). Finally, I subtract my estimate of the Economic Pay Ratio from the Simple Pay Ratio to obtain the Unexplained Pay Ratio, or $U P R$, a proxy for the portion of pay disparity not driven by economic factors. I find that this measure of unexplained pay disparity is negatively related to the likelihood of being named one of Fortune's "100 Best Places to Work," as well as to a proxy for employee turnover and a measure of pay fairness developed by JUST Capital (a non-profit organization that rates companies on various aspects of their social impact), providing support for the notion that my estimate does capture, at least to some extent, the construct of interest.

I then examine how these measures of pay disparity relate to future firm performance, measured as year-ahead industry-adjusted return on net operating assets (Adj RNOA). In multivariate analyses I find no association between the Simple Pay Ratio (the unadjusted CEO pay ratio) and subsequent firm performance. However, pay ratios based on explained and unexplained compensation tell a different story. The Unexplained Pay Ratio exhibits a negative association with subsequent firm performance, suggesting, consistent with Equity Theory, that unjustified pay disparity (i.e., the portion unrelated to economic factors) can have detrimental effects on firm performance. In contrast, consistent with Tournament Theory, I find a strong positive relation between the Economic Pay Ratio and firm performance.

The pay disparity-performance relations are economically significant: A one standard deviation increase in the unlogged Unexplained (Economic) Pay Ratio is associated with a $-1.80 \%$ $(1.46 \%)$ change in $\operatorname{Adj} R N O A$. The results are robust to alternative measures of accounting performance (unadjusted RNOA, industry-adjusted return on assets, and percent change in total 
sales), to re-estimating the pay ratios using the top five executives' compensation instead of CEO compensation as the numerator, and to controlling for pay disparity among the top five executives (the CEO pay slice, calculated following Bebchuk et al. 2011) and for excess CEO pay. In addition, much of the negative relation between unexplained disparity and performance is driven by instances where the CEO is overpaid and employees are underpaid, suggesting that the documented relation is not driven only by a numerator effect (the negative effects of excess CEO pay on performance, as shown in Core, Holthausen, and Larcker 1999). ${ }^{5}$

Lastly, to gain greater insights into the relation between the Unexplained Pay Ratio and firm performance, I examine two additional cross-sectional predictions. First, if the unexplained portion of pay disparity reflects an unfair distribution of rents within the firm rather than economic factors, I would expect a more pronounced negative relation between the Unexplained Pay Ratio and performance when the quality of corporate governance is poor. Using two proxies for weak governance (higher Entrenchment Index (Bebchuk, Cohen, and Ferrell 2009) and lower institutional ownership), I find evidence consistent with this prediction. Second, I examine a potential channel through which unexplained pay disparity may affect performance, employee turnover. Employees dissatisfied with perceived pay inequity are more likely to leave the firm (Bloom and Michel 2002). Replacing these employees is costly (search costs, training new employees, short-term decline in productivity) and may have a negative impact on performance. I find that the negative relation between the Unexplained Pay Ratio and subsequent firm

\footnotetext{
${ }^{5}$ Because compensation, and therefore disparity, is likely determined, in part, by factors related to firm performance, I take several steps to overcome concerns about endogeneity. First, in all my regressions, Adj RNOA is measured in the subsequent year to mitigate reverse causality concerns (i.e., that performance is driving the ratio). Second, I include firm fixed effects in my regressions to control for unobservable time-invariant firm characteristics. Third, I include contemporaneous Adj RNOA among the independent variables to control for potential omitted variables (Bova, Kolev, Thomas, and Zhang 2015). Fourth, I redo my tests using industry-adjusted ratios (Bebchuk et al. 2011). My inferences remain unchanged in all of these specifications.
} 
performance is more pronounced in firms with lower employee satisfaction and those facing higher employee turnover and tighter labor markets (i.e., firms in industries with more employee mobility and thus higher turnover risk).

This study makes several contributions. First, it extends the literature examining the relation between firm-level pay disparity and firm performance, and especially, a series of studies examining CEO pay ratios, which have found mixed results (Faleye, Reis, and Venkateswaran 2013; Crawford, Nelson, and Rountree 2016; Mueller, Ouimet, and Simintzi 2016; Shin, Kang, Hyun, and Kim 2015). Instead of relying on measures of total (unadjusted) pay disparity, I separate pay disparity driven by economic factors from pay disparity due to other reasons and document a different effect on performance, offering a potential explanation for the conflicting results of these prior studies. ${ }^{6}$ Also, my data allow me to examine a broad and fairly representative sample of U.S. firms, while prior studies have examined either foreign firms (Mueller et al. 2016; Shin et al. 2015), or a subset of U.S. firms providing employee pay data either voluntarily (Faleye et al. 2013) or because of industry regulation (such as banks) (Crawford et al. 2016), making their findings less generalizable.

Second, this study contributes to the nascent literature examining how corporate culture relates to the firm. There exists a wealth of anecdotal evidence about the importance of corporate culture, and recent survey evidence finds that executives believe improving culture increases firm

\footnotetext{
${ }^{6}$ The only study I am aware of that attempts to separate expected and unexpected portions of the pay ratio is Shin et al. (2015), which finds a negative relation between the unexplained pay ratio and performance for firms in South Korea, where disclosure of total employee pay is mandatory. My study offers two key advantages. First, income inequality in South Korea is small and, unlike the United States, has been declining during the last 30 years (Cobb 2016). Indeed, in the Shin et al. sample, the mean ratio of top executives' pay to average employee pay is only 7. Hence, it is a less powerful setting to investigate my research question and raises concerns of generalizability to the U.S. setting. Second, the authors identify the unexplained portion of the pay ratio by directly modeling the pay ratio as a function of a series of determinants. In contrast, I model separately the expected values of CEO pay (numerator) and employee pay (denominator) and use them to estimate the unexplained portion of the pay ratio. As discussed in detail in Section 4, my approach allows for a more precise estimate because the economic factors affecting pay differ between CEO pay and employee pay.
} 
value (Graham, Harvey, Popadak, and Rajgopal 2017). Due in part to a lack of large-scale crosssectional data on corporate culture, though, there has been little other empirical research. ${ }^{7}$ This paper provides evidence that pay disparity matters to employee satisfaction, with consequences for firm performance. In addition, the results suggest that employees are at least partly aware of how economic determinants shape the distribution of compensation and react differently to different types of pay disparity.

Third, my study may have significant implications for practitioners and policymakers. Beginning with their 2018 proxy disclosures, firms will be required to report a CEO pay ratio based on the pay of the median employee. ${ }^{8}$ A key concern about this requirement is that numerous factors unrelated to pay fairness go into compensation decisions, making it impossible for investor to determine what is a "good" or "bad" ratio (e.g., Harsen, Ward, and Buyniski 2010). My analysis highlights how a significant portion of the variation in CEO pay ratios is driven by the denominator and draws attention to the importance of controlling for economic factors affecting employee pay. In doing so, it provides investors and proxy advisors with a roadmap to interpret pay ratios and pay disparity, and may cause regulators and firms to, respectively, mandate and prepare more informative disclosures. ${ }^{9}$

Lastly, I provide a methodological contribution to researchers interested in using BLS and other longitudinal government databases, such as those available through the U.S. Census Bureau. One problem preventing broader use of these databases has been researchers' inability to connect

\footnotetext{
${ }^{7}$ The exception is the literature on two components of corporate culture, trust in management and general workplace conditions, which have been shown to be related to financial reporting quality and financial performance (Mayer and Gavin 2005; Edmans 2011; Goergen, Chahine, Brewster, and Wood 2013; Garrett, Hoitash, and Prawitt 2014)

${ }^{8}$ Note that the new SEC disclosure focuses on median employee compensation. My data do not allow me to identify the median employee.

${ }^{9}$ Crawford et al. (2016) provides some evidence that voting shareholders use information about unadjusted CEO pay ratios when casting votes on say-on-pay resolutions. A better understanding of the drivers of CEO pay ratios may lead to more informed voting decisions.
} 
physical business locations to parent companies, making firm-level examinations using these rich data sources impossible (Handwerker and Mason 2014). ${ }^{10}$ I develop a method to effectively aggregate these comprehensive establishment-level data to the firm level, creating a new database that may be exploited to examine a number of research questions concerning business organizations and their employees.

\section{Related literature and prediction development}

The term "pay disparity" has numerous definitions. Pay disparity can measure the variation in pay among people doing the same job (horizontal disparity), the variation in pay between people doing different jobs (vertical disparity), or the variation in pay among all workers in an organization (overall disparity). Most research to date has focused on the effects of horizontal or overall disparity (Gupta et al. 2012; Downes and Choi 2014). Since this study explores the characteristics of vertical pay disparity, I restrict most of the discussion in this section to prior literature on vertical disparity. Going forward, I use the term "pay disparity" to refer to vertical pay disparity unless otherwise noted.

\subsection{Pay disparity in organizations: theory and evidence}

Much of the empirical literature on pay disparity explicitly tests one of two seemingly competing economic theories. Tournament Theory predicts a positive relation between pay disparity and worker effort (Lazear and Rosen 1981). Under this theory, as pay disparity between job levels increases, the value of receiving a promotion also increases, encouraging greater effort. Numerous empirical studies have found support for Tournament Theory when examining, for

\footnotetext{
${ }^{10}$ While the Census data provide firm level identifiers for establishments, Handwerker and Mason (2014) find these lists to be incomplete. Perhaps more concerning, the authors find in their sample that $62.5 \%$ of establishments are incorrectly identified as belonging to the firm in question.
} 
example, pay disparity among executives in U.S. firms, or among white-collar workers in Europe (Main et al. 1993; Heyman 2005; Lee et al. 2008; Kale et al. 2009).

Alternatively, Equity Theory states that pay disparity leads to feelings of unfairness, resulting in lower-paid employees taking actions detrimental to firm performance, such as shirking or quitting (Akerlof and Yellen 1990). Equity Theory relies heavily on psychological research in social comparison, which posits that lower-level employees determine the fairness of their compensation by judging it, in part, against those above them in the hierarchy (e.g., Martin 1982; Dornstein 1988). Employees may care more about their relative pay than their absolute pay, and this relation has been shown to be asymmetric, with the dissatisfaction of those at the bottom greater than the satisfaction of those at the top (Bloom and Michel 2002; Card, Mas, Moretti, and Saez 2012). Several studies find evidence in support of Equity Theory when examining, for example, pay disparity among executives in U.S. firms, or among manufacturing workers (Cowherd and Levine 1992; Bloom and Michel 2002; Bebchuk et al. 2011).

While most empirical studies examining pay disparity at the firm level have focused on disparity among executives (or among supervisors and their direct reports), recent studies have attempted to examine pay disparity between the top level of the organization (CEO) and the “average" employee. Given the CEO's visibility and the detailed information available on CEO pay, it has been argued that employees will use CEO pay as a reference in determining the fairness of their own compensation, suggesting that CEO pay ratios may be useful summary measures of corporate pay disparity (Wade, O'Reilly, and Pollock 2006). Even in these studies, evidence on the relation between the CEO pay ratio and organizational performance is mixed. ${ }^{11}$

\footnotetext{
${ }^{11}$ In a sample of U.S. firms (mostly banks) that publicly disclose total employee compensation, Faleye et al. (2013) finds a positive relation between the CEO pay ratio and firm performance. Crawford et al. (2016) reports a similar finding for U.S. commercial bank holding companies, which are subject to mandatory disclosure of total employee pay. In contrast Shin et al. (2015) finds a negative relation for firms in Korea, where disclosure of employee pay is
} 


\subsection{Toward a better theory: explained versus unexplained pay disparity}

I argue that a potential reason for the inconsistent results in studies of corporate pay disparity is that they do not take into account how compensation is determined, and therefore, the sources of and reasons for pay disparity. Without controlling for various determinants of CEO and employee compensation, when testing Tournament and Equity theories researchers fail to separate income inequity, which is the notion that these differences are unfair or perceived as such, from income inequality, or the difference in compensation between groups (Trevor et al. 2012). Compensation based on measurable attributes related to factors such as performance and labor market characteristics creates pay disparity (or income inequality) but may motivate employees to perform better - consistent with Tournament Theory — without necessarily creating a perception of income inequity since compensation decisions would be viewed as fair reflections of skill and effort. In contrast, pay disparity created by factors unrelated to economics, such as the distribution of rents or favoritism, may create feelings of resentment, leading to actions that are detrimental to the firm, consistent with Equity Theory. To the extent that pay disparity reflects both economic and non-economic factors, any association between unadjusted pay ratios and performance could be misinterpreted and lead to incorrect inferences. ${ }^{12}$

The large increase in the use of performance-based pay in recent decades exacerbates this problem. Performance-based pay is designed to distribute compensation based on effort and performance, but it also increases pay disparity within an organization as some workers outperform others (Lemieux 2008; Trevor et al. 2012). Arguably, pay disparity induced by performance-based

mandatory. Mueller et al. (2016), using a proprietary dataset that reports average wages at different job levels for each firm, finds a positive relation for a sample of public and private firms in the United Kingdom. As discussed in the Introduction, these studies are subject to generalizability concerns.

${ }^{12}$ As Shaw, Gupta, and Delery (2002) puts it, “... [pay] dispersion per se is neither functional nor dysfunctional; rather, situational contingencies determine the strategic effectiveness of dispersion (or lack thereof)" (pg. 504). 
pay is not only consistent with Tournament Theory in that it encourages and rewards effort but is also consistent with Equity Theory since the distribution of pay will be perceived as fair and equitable because it reflects economic factors and performance.

\subsection{Pay disparity and firm performance: predictions}

The above arguments lead to my main set of predictions:

Pla: Pay disparity created by unexplained compensation is negatively related to firm performance;

Plb: Pay disparity created by explained compensation is positively related to firm performance;

where unexplained (explained) compensation indicates the portion of compensation driven by noneconomic (economic) factors.

For a narrow sample, Trevor et al. (2012) tests a similar set of predictions in a horizontal pay disparity setting. Examining National Hockey League players, the authors find that pay disparity resulting from players' individual performance (i.e., from an "economic" factor) is positively related to team performance, while the relation between pay disparity unexplained by individual performance and team performance is either insignificant or marginally negative. Fundamentally, my study uses the same intuition and extends this approach to the case of vertical pay disparity in the corporate setting. In this setting, two significant challenges arise. First, the set of economic factors affecting compensation is substantially more complex than in the case of NHL players. Second, when examining vertical pay disparity, it is necessary to identify these factors for different types of jobs (i.e., the CEO and the "average employee"). While there is an extensive literature on the determinants of CEO pay, modeling the portion of employee compensation driven by economic factors across different types of firms with different workforce compositions and 
operating in different labor markets is a challenging task, both conceptually and in terms of obtaining the relevant data.

\subsection{Examining factors that may influence the relation between unexplained pay disparity and firm} performance

In this section, I develop predictions about how the relation between unexplained pay disparity and performance may vary in the cross section based on certain firm characteristics.

\subsubsection{The roles of the numerator and denominator in the negative UPR-performance relation}

The goal of the SEC's pay ratio disclosure is to give investors and employees insights into whether pay within the firm is fair (Menendez 2011). Determining whether pay is fair involves comparison within the hierarchy, and pay fairness is expected to have consequences for the firm (Martin 1982; Dornstein 1988; Akerlof and Yellen 1990; Bloom and Michel 2002). While prior literature has shown that excess CEO pay is negatively related to future firm performance, in the context of pay fairness, unexplained employee pay should also influence the relation between compensation and performance (Bloom and Michel 2002; Core et al. 2002). If unexplained pay disparity is, in part, capturing the distribution of compensation that in unrelated to observable economic characteristics, and employees are aware of how economic determinants shape compensation, then the negative unexplained pay disparity-performance relation should be strongest for firms where unexplained CEO pay is positive and unexplained employee pay is negative, leading to the following prediction:

$P 2$ : The negative relation between unexplained pay disparity and performance is stronger when both the CEO is overpaid (positive unexplained pay) and employees are underpaid (negative unexplained pay).

\subsubsection{Using corporate governance quality to identify 'inequitable' pay disparity}


If the unexplained portion of pay disparity reflects, in part, an unfair (i.e., economically unjustified) distribution of rents within the firm, I would expect a more pronounced negative relation between unexplained pay disparity and performance when corporate governance is weak. Put differently, since there is measurement error in my estimate of unexplained pay disparity, one may view the subset of firms with greater unexplained pay disparity and poor governance quality as having unexplained pay disparity that is more likely to reflect inequity in rents distribution as the result of agency problems, and, thus, more likely to negatively affect performance, leading to the following prediction:

P3: The negative relation between unexplained pay disparity and firm performance is stronger for firms with weaker governance.

\subsubsection{How does unexplained pay disparity affect performance? The employee turnover channel}

When employees deem that their pay is unfair, Equity Theory predicts that they will take actions to recoup their compensation in ways that are detrimental to the firm, such as shirking (Akerlof and Yellen 1990). Among others, a specific channel through which unexplained disparity may lead to decreased firm performance is turnover, which is costly to the firm in terms of search and training of new employees, and reduced productivity in the short term. Bloom and Michel (2002) finds empirical evidence that greater pay disparity among firm managers leads to a higher likelihood of turnover. The willingness to quit in response to unjustified pay disparity, though, is likely partially determined by an employee's outside options. When the labor market is tighter (i.e., more job openings and fewer layoffs), it is less risky for employees to quit in response to perceived pay inequity since the probability of getting a new job is greater. These arguments lead to the following predictions: 
P4a: The negative relation between unexplained pay disparity and firm performance is stronger for firms with lower employee satisfaction;

$P 4 b$ : The negative relation between unexplained pay disparity and firm performance is stronger for firms with higher employee turnover;

$P 4 c$ : The negative relation between unexplained pay disparity and firm performance is stronger for firms in industries with tighter labor markets.

\section{Compensation data}

One significant challenge of examining questions related to non-executive compensation at the firm level is a lack of available data. As stated above, studies have relied on data from voluntary disclosures, specific industries where disclosures are mandated, or countries with disclosure mandates, but generalizability is a concern in these studies (e.g., Faleye et al. 2013; Shin et al. 2015; Crawford et al. 2016). While BLS and other government agencies make compensation data available to academic researchers, aggregating these data to the firm level poses a significant challenge (Handwerker and Mason 2014). Below, I describe the data I use and the technique I apply to effectively aggregate non-executive compensation data to the firm level for a large sample of publicly traded firms.

This study relies on two confidential databases maintained by the BLS, the Quarterly Census of Employment and Wages (QCEW) and the Occupational Employment Statistics survey (OES), both of which cover almost every employee in the United States. QCEW reports two items at the establishment-quarter level relevant to this study, total establishment compensation and total number of employees. ${ }^{13}$ Establishment compensation includes salaries, cash bonuses, share-based

\footnotetext{
${ }^{13}$ The QCEW database is created at the state level, and states must grant permission to outside researchers to use the data. Several states grant access either on a case-by-case basis or not at all. The states that refused access for this project are Florida, Kentucky, Massachusetts, Michigan, Mississippi, New Hampshire, North Carolina, Oregon, Pennsylvania, and Wyoming.
} 
compensation, profit sharing pay, and gratuities paid during the quarter. OES reports detailed information on the types of jobs and the number of people working in those jobs in each establishment, which allows for the measurement of economically meaningful establishment characteristics. All employees included in OES are classified into one of 840 Standard Occupational Classification (SOC) codes, as defined by BLS. ${ }^{14}$

\subsection{Creating a firm-level database}

Aggregating BLS establishment data to the firm level in a large sample is a significant challenge because establishments do not share common firm-level identifiers. In addition, establishment names, which can vary for establishments in the same firm, do not allow for structured merging to the firm level (Handwerker and Mason 2014) ${ }^{15}$ Below, I describe a multistep process that enables me to overcome these challenges through the merging of several databases and hand checking of results. A similar methodology can be implemented for future firm-level studies that rely on BLS data. Figure 1 provides a graphical explanation of how the databases are merged. Table 1 describes how the number of firms and establishments in the sample changes in each step.

The goal of this process is to attach a common firm-level identifier (GVKEY) to each establishment belonging to that firm. I begin by merging Compustat, CRSP, and Execucomp on common identifiers to create the possible universe of firm-years with available data (the "financial database" in Figure 1). I drop all firm-years with missing relevant data and those with CEO

\footnotetext{
${ }^{14}$ OES also reports wage information, but because establishments are surveyed randomly and sporadically, creating a time series at the establishment level is impossible, as is creating meaningful firm-year measures since establishments in the same firm aren't necessarily surveyed in the same period. For my measures using OES that are described in Section 4.1, I require establishments to be surveyed at least once in my sample period, and match the variables from OES to the most recent establishment-year in QCEW.

${ }^{15}$ One approach to match firms to BLS establishments is to use ReferenceUSA, as in Michaels, Page, and Whited (2015). However, this approach is prohibitively expensive for a large sample because it requires payment for each establishment.
} 
turnover. Next, I scrape the SEC's EDGAR FTP server for Exhibit 21 of all firms' 10-Ks to extract a list of subsidiaries, as well as the firm's CIK identifier and filing date. In Step 1, I merge GVKEY, fiscal year end date, headquarters address, headquarter geographic coordinates, website address, and IRS Employer Identification Number (EIN) from the financial database to each subsidiary name (from Exhibit 21) belonging to the same firm in the same year.

Next, I merge these data with Factual, a database of approximately 20 million U.S. business establishment addresses. Factual's database includes the establishment business name, its address, its website, its geographic coordinates, and its "chain name," or the name of the company that owns the establishment, where available. In Step 2, I first normalize the text in both databases, removing words and abbreviations like "co." and "corp." from company names, as well as making address abbreviations and website addresses consistent (e.g., removing "http:/" from the start of all websites). I then merge the data by matching, in order, website addresses, geographic coordinates, physical addresses, and chain names. For establishments where I do not find a successful match on this first merge, using the SequenceMatcher fuzzy matching tool in Python's difflib package, I do another merge on company, subsidiary, and establishment name, dropping all matches that score below 0.85 (out of 1). These techniques yield 550,828 successful matches. I then hand check all of the name-based matches since fuzzy matching leads to false positives. ${ }^{16}$ After hand checking, I am left with 215,808 successful matches that include establishment name, address and geographical coordinates, parent company name, GVKEY, and parent EIN (which may differ from establishment EIN, as shown in Handwerker and Mason 2014).

In Step 3, these data are uploaded to the BLS server and merged with QCEW by, in order, EIN, geographic coordinates, establishment address, and fuzzy matching of establishment name

\footnotetext{
${ }^{16}$ Three research assistants assisted with the hand checking of the data. When it was uncertain whether a match was correct, Google search and Google Streetview were used to confirm the match.
} 
(before the merge, I normalize the QCEW database using a process similar to the one described above). This merge is hand checked again. Finally, in Step 4, I merge the OES data on unique BLS establishment identifiers. The resulting database contains establishment-level variables as described below, as well as unique firm identifiers and fiscal year-end date, making aggregation to the firm-year level trivial. The process yields a firm-year database consisting of 21,852 establishments (104,748 establishment-years) for 931 unique firms (5,208 firm-years) from 2006 to 2013. It is important to note that BLS provides air-gapped computers to researchers to protect the confidential data it collects. Thus, all outside data and statistical outputs must be, respectively, uploaded and downloaded by BLS staff.

\section{Modeling employee pay and CEO pay}

One goal of this paper is to identify the portion of pay disparity explained by economic factors and the portion unexplained by these factors. To do so, I subtract from the Simple Pay Ratio (total CEO pay/total mean employee pay) an estimate of what I call the Economic Pay Ratio, or $E P R$, which is the ratio of the explained portion of CEO pay to the explained portion of employee pay. This requires that I separately model explained CEO pay (numerator) and explained employee pay (denominator). For the former, I largely rely on the extensive literature on CEO pay. For the latter, I use the establishment-level employee compensation database described above.

Note that an alternative approach would be to directly estimate the explained component of the Simple Pay Ratio (as in Shin et al. 2015) and use the residual to capture the unexplained portion of the Simple Pay Ratio (my proxy for firm-level pay disparity). However, this approach assumes that the researcher can model the determinants of the pay ratio. In reality, different economic forces drive the CEO labor market and employees' labor markets, making it difficult to properly capture them both in a single model of the CEO pay ratio. By separating the numerator 
and denominator, and building a "bottom up" model of employee pay from the establishment-level compensation data, my approach allows for a more precise estimation of the two components of the ratio and, thus, its unexplained portion.

\subsection{Modeling establishment-level employee compensation}

Based on insights from prior studies (e.g. Groshen 1991a, 1991b) and taking advantage of my establishment-level data, I model mean employee pay at the establishment level as follows:

$$
\begin{aligned}
\text { Mean pay }_{i, j, t} & =\alpha+\sum_{a} \beta_{a} \text { Establishment factors }_{i, j, t}+\sum_{b} \beta_{b} \text { Macroeconomic factors }_{i, j, t} \\
& +\sum_{c} \beta_{c} \text { Firm factors }_{i, t-1}+\text { industry fixed effects }+ \text { year fixed effects } \\
& +\varepsilon, \quad(1)
\end{aligned}
$$

where, for each establishment, Mean pay is the average yearly employee compensation calculated as the total yearly employees' compensation divided by the average number of employees during the year, as reported in QCEW. Establishment factors, Macroeconomic factors, and Firm factors are, respectively, a vector of establishment-level, local macroeconomic-level, and firm-level variables hypothesized to be associated with employees' pay. Industries are defined by the twodigit SIC code. Subscript $i$ is the firm identifier, $j$ is the establishment identifier, and $t$ is the fiscal year. The compensation predicted by this regression is the explained component of mean compensation, whereas $\varepsilon$ captures the component not explained by the model. Table 2 describes the predicted relation between Mean pay and each of the factors, which are detailed below. All variables are defined in the Appendix.

Establishment factors include the following establishment-level variables constructed from the BLS databases (OES and/or QCEW): the percent of employees working, respectively, in research and development jobs ( $R \& D$ emp pct), non-R\&D technology fields (Tech emp pct), non- 
retail sales (Sales emp pct), retail (Retail emp pct), non-financial services (Services emp pct), and manufacturing-related jobs (Manufact emp pct). ${ }^{17}$ These categories are mutually exclusive in the sense that each employee can be classified as being in only one of these five groups. I also construct a corresponding set of indicators equal to 1 if an establishment has any $R \& D$ workers $(R \& D$ indicator), non-R\&D technology workers (Tech indicator), non-retail sales workers (Sales indicator), retail workers (Retail indicator), non-financial services workers (Services indicator), and manufacturing workers (Manufact indicator). Including these indicators allows me to control for the effect of the presence of certain types of employees on the establishment's overall compensation practices, regardless of their numbers.

In addition, I include the percent of employees with supervisory duties (Pct supervisor) and construct an indicator equal to 1 if the BLS database reports that executives work in the establishment (Exec indicator). ${ }^{18}$ Finally, Ch emp is the percent change in the number of employees from the previous year. All variables are measured using OES data except for Ch emp, which is measured using QCEW. See the Appendix for detailed definitions.

The above variables are hypothesized to affect establishment-level mean employee pay. For example, all else being equal, I expect the presence of a larger fraction of R\&D or technology employees in the establishment to be associated with higher employee pay, since these employees have specialized skills. In contrast, I expect a higher presence of low-skilled workers (e.g. retail,

\footnotetext{
${ }^{17}$ All establishments are required to report to the BLS the number of employees working in each of the 840 SOC job codes. The codes used in the compensation model were chosen for two reasons. First, there is a clear prediction of their relation to compensation. Second, they are among the most common job categories in my sample and are present across multiple industries.

${ }^{18}$ I do not include an indicator corresponding to Pct supervisor because each establishment has at least one employee with a supervisor role. As for Exec indicator, I do not include the percentage of employees classified as top executives because it is extremely small and usually for each firm only one or a few establishments include top executives.
} 
non-financial services) to result in lower mean employee pay at the establishment level (see Table 2 for more details).

Macroeconomic factors include the following local macroeconomic variables related to the labor market, measured at the Metropolitan or Micropolitan Statistical Area closest to the establishment: the industry-region average compensation (Ind-region comp) and the percent of residents who graduated from college ( $\mathrm{Col} \mathrm{grad})$. I also include an indicator equal to 1 if the establishment is located in a state that has passed a "Right to Work" law (Right to work). ${ }^{19}$ All variables are publicly available through the U.S. Census Bureau, except Right to work, which is hand collected. Since pay levels are shaped by the labor market, average employee pay in the same region and industry should be positively related to establishment compensation. Hence, I expect a positive association between Ind-region comp and Mean pay. In contrast, "Right to Work" laws have been shown to weaken union influence, and union presence has been found to be positively associated with employee pay levels (e.g., Cowherd and Levine 1992; Lemieux 2008). Thus, I expect a negative association between Right to work and Mean pay.

Finally, as for the Firm factors, I include several firm characteristics generally known to affect compensation: size (Ln assets, the natural log of total assets), age (Ln age, the natural log of the number of years since the firm first appeared in CRSP), R\&D intensity $(R \& D /$ sales, research and development costs scaled by total sales), profitability (Adj RNOA, industry-adjusted return on net operating assets), volatility ( $R N O A$ var, the rolling five-year standard deviation of $A d j R N O A$ ), Labor productivity (total sales divided by total employees), Capital intensity (capital expenditures divided by total sales), Leverage (total debt divided by total assets) and growth options (BTM, the book-to-market ratio). All variables are from Compustat except Ln age. All continuous variables

\footnotetext{
19 "Right to work" laws prohibit agreements that set strict conditions on the unionization of certain jobs, making it more difficult to create and grow union representation.
} 
listed above are winsorized at $1 \%$ and $99 \%$ to reduce the influence of outliers. See the Appendix for detailed variable descriptions. ${ }^{20}$

One concern with my data and my model is that I lack data on individual wages and individual characteristics, such as education level, tenure, race, and gender, that may explain such wages (e.g., Abowd, Kramarz, and Margolis 1999). Several studies, though, suggest that this may not be a serious concern (e.g. Groshen 1991a; Groshen 1991b; Barth, Bryson, Davis, and Freeman 2014). A persistent result in the literature on wages is that where a person works (i.e., industry, firm, and establishment) is the strongest predictor of wage variation. For example, Groshen (1991a) finds that the establishment where a person works explains more of intraindustry wage differentials than the individual characteristics of employees. Groshen (1991b) shows that establishment and occupation explain $90 \%$ of compensation for manufacturing workers and that a random change in job is associated with a $10-15 \%$ change in compensation. In addition, recent research has shown that establishment and firm characteristics have been largely responsible for the growth in income inequality in recent years. ${ }^{21}$ Consistent with these studies, as shown in Section 5.2, the explanatory power of my model is relatively high.

\subsection{Modeling CEO compensation}

Based on an extensive literature that examines how firm-level economic determinants relate to CEO compensation (e.g., Core et al. 1999; Gipper 2016), I model CEO pay as follows:

\footnotetext{
${ }^{20}$ Firm factors, as well as the establishment-level factor Ch emp, are measured in year t-1 since QCEW reports compensation when it is paid (rather than when it is earned). As such, compensation paid in year $\mathrm{t}$ is, in part, a function of firm characteristics (e.g., performance) in t-1.

${ }^{21}$ Barth et al. (2014) provides evidence that the growth in pay dispersion in the United States has been due to changes in dispersion between establishments, as opposed to within establishments. Similarly, Song, Price, Guvenen, Bloom, and von Wachter (2015) finds that almost all of the rise in the dispersion in earnings from 1978 to 2012 can be attributed to growing dispersion between firms, while dispersion within firms has remained stable.
} 


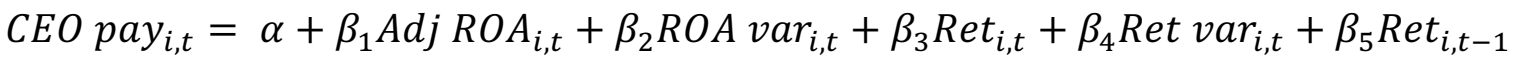

$$
\begin{aligned}
& +\beta_{6} \text { Ln CEO tenure }_{i, t}+\beta_{7} \operatorname{LnCEO} \text { age }_{i, t}+\beta_{8} \text { Outside CEO }_{i, t}+\beta_{9} \text { Loss }_{i, t} \\
& +\beta_{10} \text { Log Assets }_{i, t}+\beta_{11} \text { BTM }_{i, t}+\beta_{12} \text { Leverage }_{i, t}+\text { industry fixed effects } \\
& + \text { year fixed effects }+\varepsilon \text {, }
\end{aligned}
$$

where subscripts are defined as above. CEO pay is total compensation, as measured by Execucomp. Since CEOs have decision-making power for both operations and financing, I include industry-adjusted ROA ( $\operatorname{Adj} R O A)$ as a measure of accounting profitability. A significant portion of CEO compensation comes from share-based compensation, so stock returns (Ret) should positively influence compensation, and firms with noisier measures of performance, as measured by the standard deviation in monthly returns for the prior 60 months (Ret var) and the standard deviation in $A d j R O A$ for the prior five years ( $R O A$ var), should provide stronger incentives (Core et al. 1999). Ln CEO tenure and Ln CEO age are the natural log of the number of years the CEO has served in that position and the CEO's age, respectively, and are expected to be positively related to pay. Outside $C E O$, an indicator equal to 1 if the CEO came from outside the firm, should be positively associated with pay. Loss is an indicator equal to 1 when net income is negative, a proxy for poor performance. Ln assets is a measure of size, which is a proxy for CEO talent and firm complexity (Core et al. 1999). The book-to-market ratio is strongly negatively correlated with profitability. Since more profitable firms pay more, I expect BTM to be negatively related to compensation (Abowd et al. 1999). Leverage measures the riskiness of the firm, as well as its ability to pay, so I do not predict the sign of the relation with compensation. ${ }^{22}$ See the Appendix for detailed definitions of all variables.

\footnotetext{
${ }^{22}$ Unlike the variables used in the establishment-level model, here I regress contemporaneous independent variables on total CEO compensation since CEO compensation, as reported in Execucomp, includes incentive compensation based on contemporaneous firm characteristics.
} 


\section{Empirical analysis}

\subsection{Descriptive statistics}

Table 3, Panel A provides descriptive statistics comparing the firms in my sample to the rest of the firms in Execucomp (which covers approximately the S\&P 1,500 firms) for the 20062013 period. My sample covers 40.3\% (5,082/12,607) of the firm-year observations in Execucomp. For most of the firm characteristics discussed earlier, the differences are statistically significant but economically small. For example, mean total assets (Assets) is $\$ 15.4$ billion for my sample and $\$ 13.5$ billion for the other firms in Execucomp. Book-to-market (BTM) is 0.53 for my sample and 0.57 for the other firms in Execucomp. Industry composition is also similar (Table 3, Panel B), except that my sample has a greater (smaller) proportion of firms in the machinery and business equipment (financial services) sector. Overall, Table 3 suggests that my sample is representative of the S\&P 1,500 firms.

Table 4, Panel A provides descriptive statistics on the establishment-level variables. On average, each establishment has 80 employees. The mean employee compensation (Mean pay) averages $\$ 42,070 /$ year, with a median of $\$ 27,160$ and a standard deviation of $\$ 40,170$. The substantial variation in this variable has important implications for the interpretation of the CEO pay ratio data that firms will start disclosing in 2018. It suggests that variation in the CEO pay ratio is not only the effect of variation in CEO pay, but also variation in employee pay. As noted below, to the extent that such variation reflects differences in economic factors (i.e. composition of workforce), for the ratio to provide useful and comparable information, it is essential to understand the drivers of employee pay across industries and firms. 
R\&D (technology) employees are present in $14.8 \%$ (17.3\%) of establishments. Retail employees and non-financial services employees are present in $46.7 \%$ and $40.4 \%$ of establishments, respectively, suggesting that many of the sample establishments are businesses such as chain stores and restaurants, which is unsurprising, given the prevalence of retail establishments and restaurants across all regions of the United States. Table 4, Panel B supports this result, showing that $42.8 \%$ of establishments are in the retail industry.

I next look at how Mean pay varies across establishments depending on workforce composition. Table 4, Panel C shows that establishments where work is conducted by $\mathrm{R} \& \mathrm{D}$, technology, non-retail sales, and manufacturing workers, and executive employees have significantly higher compensation, while those that employ retail and services workers have significantly lower compensation, on average. These univariate statistics confirm most of the workforce composition predictions in Table 2. More importantly, they highlight the denominatorinduced problems in comparing CEO pay ratios across firms. The executive pay literature has long established that CEO pay levels (the numerator) cannot be compared across firms without taking into account key determinants, such as size, performance, and industry. This study highlights an analogous denominator-induced problem: Average employee pay levels cannot be compared across establishments/firms without taking into account differences in economic factors explaining employee pay, such as the composition of the workforce. Two firms with similar CEO pay levels but differences in workforce composition will have substantially different mean/median employee pay, leading to potentially large, misleading differences in (unadjusted) CEO pay ratios.

Table 4, Panel D reports the correlation matrix for my establishment-, macroeconomic-, and firm-level variables at the establishment level, with Pearson correlations below the diagonal and Spearman correlations above. The correlations between Mean pay and the establishment-level 
variables are generally consistent with the univariate differences in Panel B. A strong correlation exists between Ind-region comp and Mean pay (Spearman correlation of 0.54), suggesting that the industry-region average employee pay measure, publicly available through the U.S. Census Bureau, can offer some guidance when firm and establishment compensation data are unavailable. Turning to firm-level variables, a strong positive relation exists between Mean pay and firm size, age, R\&D intensity, and labor productivity, suggesting that firm-level characteristics are also important in understanding employee pay at the establishment level.

\subsection{Determinants of establishment-level employee pay and CEO pay}

Table 5, Panel A reports the results of implementing the establishment-level employee compensation model described in Equation (1). Column (1) presents the relation between Mean pay and the establishment-level variables. Remarkably, these variables explain more than half of the variation in Mean pay (adjusted r-squared of 52.5\%), confirming the importance of accounting for establishment-level factors when comparing employee pay across establishments. Columns (2) and (3) add the macroeconomic and firm-level variables, respectively. Column (4) includes industry and year fixed effects and is the specification I will use to calculate explained employee pay. The adjusted r-squared increases across the columns, up to $61.1 \%$ in column (4), showing that the additional variables have incremental explanatory power.

Focusing on Column (4), the independent variables are significantly related to compensation in the direction predicted in Table 2. For example, for the establishment variables, the coefficient on $R \& D$ emp pct, 53.36, is significant at the $1 \%$ level, providing evidence that a higher proportion of R\&D workers in an establishment is associated with higher mean compensation. The relation between Mean pay and the establishment variables is largely consistent with the results in Table 4, Panel C. Examining macroeconomic variables, I find that Ind-region 
comp (Right to work) is positive (negative) and significant at the 1\% (5\%) level, as predicted. Turning to the firm-level variables, the coefficients on both Adj RNOA and Labor productivity are positive and significant at greater than $1 \%$, consistent with greater average employee pay in firms with better performance and a more productive workforce. ${ }^{23}$

Panel B of Table 5 reports the results for the CEO compensation model in Equation (2). The adjusted r-squared for the model is $56.3 \%$. Consistent with prior studies, Ln assets is the strongest predictor of CEO pay, with a t statistic of 64.91. The coefficients on contemporaneous stock performance is not statistically significant, but the measures of lagged returns, accounting profitability and volatility ( $R O A$ and $R O A$ var) are positive and significant as predicted.

\subsection{Explained and unexplained pay ratios}

The Simple Pay Ratio, or $S P R$, is calculated as:

$$
S P R_{i, t}=\frac{C E O \text { pay }_{i, t}}{\text { Mean pay }}
$$

where Mean pay is mean establishment compensation aggregated to the firm level as follows:

$$
\text { Mean } \text { pay }_{i, t}=\frac{\sum\left(\text { Mean pay }_{i, j, t} \times \text { tot emp }_{i, j, t}\right)}{\sum \text { tot } e m p_{i, j, t}}
$$

and all subscripts are defined as above.

Similarly, the Explained Pay Ratio, or EPR, is calculated as:

$$
E P R_{i, t}=\frac{\text { Explained } C E O \text { pay }_{i, t}}{\text { Explained mean pay } y_{i, t}}
$$

where Explained CEO pay is the predicted compensation from running the regression described in Equation (2), and Explained mean pay is calculated as in Equation (4), except the pay component

\footnotetext{
${ }^{23}$ Since several of the variables in these regressions are strongly correlated, I check for multicollinearity by measuring the tolerance ( 1 /variance inflation factor) of relations among the variables. The lowest tolerance is 0.278 , well above the 0.1 that would warrant concern.
} 
of the numerator (Mean pay) is the predicted compensation from running the establishment-level regression described in Equation (1).

Finally, I compute the unexplained ratio as the difference between the actual ratio and the explained ratio. $^{24}$

$$
U P R_{i, t}=S P R_{i, t}-E P R_{i, t}
$$

\subsubsection{Pay ratios: descriptive statistics}

Table 6, Panel A provides descriptive statistics for the pay ratios and firm-level variables of interest. Mean $S P R$ is $101.5 .^{25}$ Mean $E P R$ is 72.7 , and $U P R$ is 23.3 . That the majority of $S P R$ is explained by economic factors suggests that ignoring these factors when examining the relation between pay disparity and firm performance could lead to false inferences. The medians of the ratios are much lower than the means, with the median $U P R$ just slightly positive (at 7.0). Because of this positive skewness, I use the natural logs of the ratios in my main analyses to reduce the influence of outliers. ${ }^{26}$ On average, the number of employees covered by my sample is $44.3 \%$ of the total number of employees reported in Compustat (variable Emp pct). The main reason for the gap is that, as discussed earlier, I was unable to collect all U.S. establishments due to states limiting access. Also, I do not have international employees in my sample, and my matching algorithm is unlikely to be perfectly accurate. In robustness tests, I rerun my main regressions below using only firms with above median Emp pct and find that this increases mean Emp pct to $74.1 \%$ without

\footnotetext{
${ }^{24}$ An alternative approach to calculating $U P R$ would be to compute the unexplained ratio as the ratio of the differences between actual and explained pay (i.e., unexplained CEO pay divided by unexplained employee pay). However, such an approach could lead to negative numbers in the numerator and/or denominator, making interpretation of the ratio impossible.

${ }^{25}$ Media articles often report a CEO pay ratio greater than 300 (e.g., Globalist 2013). The reasons for the difference between this estimate and mean $S P R$ are threefold. First, I use mean compensation instead of median. Second, I use actual employee compensation data, whereas media articles often refer to industry or survey data. Third, media estimates include only firms in the S\&P 500, which are larger firms, with higher CEO pay and thus higher ratios. Mean SPR among firms in the S\&P 500 in my sample is 175.1.

${ }^{26}$ When using unlogged ratios, my results remain unchanged.
} 
altering my results, providing evidence that the subset of excluded employees does not introduce any systematic bias.

Table 6, Panel B reports the correlation matrix of my firm-level variables of interest with Pearson (Spearman) correlations below (above) the diagonal. Focusing on Spearman correlations due to the skewness of my measures, there is a strong relation between $S P R$ and $E P R$, at 0.51 . The correlation between $U P R$ and $S P R$ is positive at 0.45 , while the correlation between $U P R$ and $E P R$ is negative at -0.24 . It is important to highlight the pay ratios' correlations with CEO pay. While the correlation between $C E O P a y$ and $S P R$ is highly positive at 0.77 , as expected, it is only 0.49 for EPR and, importantly, only 0.10 for $U P R$, suggesting that CEO pay is unlikely to drive any effect of $U P R$ on performance. As expected, higher Mean pay is associated with lower values of the three pay ratios. Unsurprisingly, given the correlation between size and CEO pay, SPR also is strongly correlated with Ln assets (0.50), while UPR's correlation with size is weaker (0.04). Supporting predictions $1 \mathrm{a}$ and $1 \mathrm{~b}$, the correlation between performance (Adj RNOA) and EPR $(U P R)$ is positive (negative) at $0.05(-0.03) .^{27}$

\subsubsection{Validating the Unexplained Pay Ratio}

To validate my estimate of the Unexplained Pay Ratio as a measure of pay fairness, I examine its correlation with three measures of employee satisfaction. The underlying premise is that if my estimate of $U P R$ does capture the portion of the pay ratio that would be viewed as "unjustified," it should be correlated with proxies for employee satisfaction. The first proxy is Fortune, an indicator equal to 1 if a firm was chosen as one of Fortune magazine's “100 Best Places to Work" in a particular year. These (and similar) data have been used as proxies for employee satisfaction and trust in management in a number of studies examining how employee

\footnotetext{
${ }^{27}$ These correlations are qualitatively similar when examining logged values of the ratios.
} 
attitudes relate to firm performance and firm value (e.g., Ballou, Godwin, and Shortridge 2003; Edmans 2011; Garrett et al. 2014). ${ }^{28}$

The second measure, JUST fair pay, is a continuous variable I calculate using data from JUST Capital, a non-profit organization that analyzes firms based on their environmental, social, and governance behaviors using a variety of public and commercial databases. In particular, I focus on a subset of four measures related to employee compensation: the number of employees earning a living wage, the commitment of the firm to combating pay discrimination, the fairness of compensation compared to others doing similar work, and the gap between executive compensation and compensation of other employees. ${ }^{29}$ I take the average of these four measures, all of which are normalized to have a mean of 50 and a standard deviation of 20. A higher value indicates that pay is perceived to be more fairly distributed throughout the organization.

The third measure, Turnover, is a proxy for employee turnover calculated following Carter and Lynch (2004) as total cancelled employee stock options (ESOs) in year $\mathrm{t}+1$ divided by outstanding ESOs in year t. If employees are dissatisfied with compensation structure, one option they have is to leave the firm. ${ }^{30}$

In Table 7, I regress each of the three measures of satisfaction on my estimate of $L n U P R$, the natural $\log$ of $U P R$. I find that firms with higher $L n U P R$ are less likely to be ranked in the Fortune 100 Best Places to Work (logit regression in Column (1)), score lower in the composite JUST Capital measure (OLS regression in Column (3)), and have higher future turnover (OLS

\footnotetext{
${ }^{28}$ Inclusion in the Fortune list is based on two components, employee responses to a survey and an outside evaluation of factors related to a firm's treatment of its employees (Edmans 2011).

${ }^{29}$ Compensation of non-executive employees is approximated by JUST Capital using data from Glassdoor, publicly available BLS industry compensation information, and other public sources.

${ }^{30}$ This is an admittedly crude proxy for employee turnover. Among other issues, it assumes that all firms use stock options to compensate lower level employees. However, Carter and Lynch (2004) shows a strong correlation between this measure, calculated at the industry level, and actual industry-level employee turnover.
} 
regression in Column (6)), providing support for the validity of my estimate of $U P R .{ }^{31}$ The results for Fortune and Just fair pay are similar in Columns (2) and (4) when controlling for a number of firm characteristics (detailed in the next section). Note that I use the natural log of all ratios in this test and all tests going forward to mitigate concerns about positive skewness. ${ }^{32}$

While $U P R$ is measured with noise, these results provide evidence that my measure is capturing the intended construct, that of pay fairness. Importantly, the negative relation between employee satisfaction and unexplained pay disparity suggests that employees understand, in part, how different components of compensation (e.g., earned pay versus unfair rent extraction) shape the distribution of compensation, and that they react negatively to disparity that is unrelated to economic factors.

\subsection{Pay ratios and firm performance}

Having validated my estimate of $L n U P R$, I next turn to my main analysis, examining the relations between the pay ratios and subsequent firm performance using the following multivariate regression:

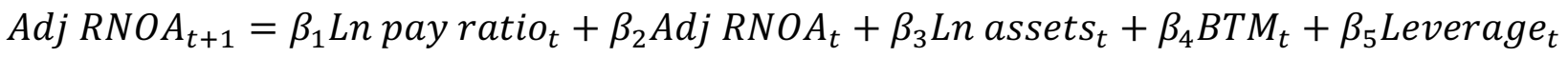

$$
\begin{aligned}
& +\beta_{6} \text { Labor productivity }_{t}+\beta_{7} \text { Capital intensity }_{t}+\beta_{8} \text { Ln age }_{t} \\
& + \text { year fixed effects }+ \text { firm fixed effects }+\varepsilon \text {. }
\end{aligned}
$$

The coefficient of interest, $\beta_{1}$, captures the association between the pay ratio and subsequent performance. While my focus is mostly on $\operatorname{Ln} U P R$ (the natural log of the Unexplained Pay Ratio), for completeness I also examine $\operatorname{Ln} S P R$ (the natural log of the unadjusted Simple Pay Ratio) and

\footnotetext{
${ }^{31}$ Because inclusion on the Fortune list is sticky and Just fair pay is measured only once for each firm, I am unable to include firm fixed effects in these regressions.

${ }^{32}$ Because UPR can be positive or negative, I calculate $L n U P R$ as $L n S P R-L n E P R$.
} 
Ln EPR (the natural log of the Economic Pay Ratio, based on the explained portions of CEO and employee pay). All variables are defined in the Appendix.

My key performance metric is $A d j R N O A$, the industry-adjusted return on net operating assets. This measure captures a firm's return on invested capital, exclusive of financing decisions. Similar to prior studies, I control for a number of firm characteristics that can potentially affect future profitability and may also be related to the pay ratios, such as firm size (Ln assets), firm age (Ln age), book-to-market ratio (BTM), Leverage, total sales scaled by total number of employees reported in Compustat (Labor productivity), and capital expenditures scaled by total assets (Capital intensity).

Table 8, Panel A presents the results from testing Equation (7) with and without control variables. Columns (1) and (5) fail to provide evidence of a significant relation between Adj RNOA and $L n$ SPR. In Columns (2) and (6), the coefficient on Ln UPR is negative and significant. In Column (6), the coefficient on UPR is -0.0013 , significant at greater than $5 \%$. I find similar significance but an opposite relation for $L n E P R$ in Columns (3) and (7) with a t statistic of 2.96 for Column (7). Economically, these results are also significant. In untabulated tests, when using unlogged ratios, I find that a one standard deviation increase in $U P R(E P R)$ is associated with a $1.80 \%(1.46 \%)$ change in $A d j$ RNOA. These results are consistent with predictions 1a and 1b.

Note that because firm performance and compensation decisions likely are jointly determined, I take steps to alleviate concerns about endogeneity. To mitigate simultaneity, Adj $R N O A$ is measured in year $\mathrm{t}+1$ in all my regressions, with $A d j R N O A_{t}$ included as an independent variable in all regressions to control for omitted variables (Bova et al. 2015). I include firm fixed effects to control for time-invariant firm characteristics and year fixed effects to control for aggregate time-series trends. Finally, following Bebchuk et al. (2011), Table 8, Panel B reports 
the results from testing Equation (7) with the logged ratios replaced by industry-adjusted logged ratios. Industry-adjusted ratios are calculated as (firm-year ratio - industry-year ratio), where industry is defined by two-digit SIC code. The above inferences remain unchanged in this specification. $^{33}$

In robustness tests (untabulated), I test whether my results are sensitive to how accounting performance is measured. To do so, I replace $A d j R N O A$ in Equation (4) with Adj ROA. In these regressions, the t statistic for $\operatorname{Ln} U P R(\operatorname{Ln} E P R)$ is -1.69 (2.00) and statistically significant at greater than $10 \%(5 \%)$. In addition, I replace the dependent variable with RNOA that is not industry adjusted, as well as contemporaneous industry-adjusted RNOA. Because compensation influences these accounting ratios, I also redo my main analysis using $C h$ rev, the percent change in revenue, perhaps a more crude measure of performance but one that excludes compensation. Finally, I calculate my ratios using top-five executive pay in the numerator and conduct my main analyses again. In all of these tests, the results remain unchanged.

5.5 Examining the drivers of the negative relation between unexplained pay disparity and performance

The previous analyses show that unexplained pay disparity (as measured by $L n U P R$ ) has a negative association with firm performance. One question that remains is, what roles do the numerator (CEO pay) and the denominator (mean employee pay) play in this relation? As shown in Table 9, Panel A, there are four possible combinations of overpaid/underpaid CEO and overpaid/underpaid employees, but when both are overpaid or underpaid, $U P R$ can be positive or

\footnotetext{
${ }^{33}$ To further allay concerns about endogeneity, in untabulated analyses I conduct two-stage least squares regressions using industry (two-digit SIC code) median pay ratios as instruments for the ratios, since industry is exogenously determined and pay levels and structure are likely to be similar within industries (Bebchuk et al. 2011; Kale et al. 2009; Murphy 1999). I expect this variable to be positively related to the firm-level ratio but be uncorrelated with the error term. My inferences remain unchanged in these analyses.
} 
negative, leading to six scenarios. For example, consider the case where both the CEO and employees are underpaid (relative to the corresponding expected pay models). In this case, $U P R$ will be positive if the employees are underpaid more than the CEO is (Case 1), and negative if they are underpaid less than the CEO is (Case 2) (since $U P R=S P R-E P R$ ). Similarly, consider the case where both the CEO and employees are overpaid: UPR will be positive if the CEO is overpaid more than employees (Case 6), and negative if the CEO is overpaid less than employees (Case 5). ${ }^{34}$ Finally, UPR will be unambiguously positive if the CEO is overpaid and the employees are underpaid (Case 3) and unambiguously negative if the CEO is underpaid and the employees overpaid (Case 4).

Analyzing these six combinations can shed light on whether the relation between $U P R$ and firm performance is driven by cases where the CEO is overpaid (numerator effect), regardless of employee pay, or by combinations of unexplained pay at both the CEO and employee level. ${ }^{35}$ To do so, I assign firms to one of the six categories described in Table 9, Panel A. Then, I examine whether indicator and semi-continuous variables capturing each of the six possible combinations are related to Adj RNOA. Table 9, Panel B reports the results of regressing indicators (interactions between indicators and $L n U P R$ ) on Adj RNOA in Column (1) (Column (2)). I find that the negative relation between $L n U P R$ and subsequent performance is largely driven by Case 3, that is, firms where the CEO is overpaid and employees are underpaid, suggesting that the interaction between

\footnotetext{
${ }^{34}$ Because $U P R$ is calculated as $S P R-E P R$, when the residuals from the expected pay models are of the same sign for both CEO pay and employee pay, the sign of UPR can be either positive or negative, depending on which residual is larger in percentage terms. Consider the following example where both the CEO and employees are overpaid, but the CEO is overpaid more in percentage terms: Actual (expected) CEO pay is $\$ 5$ million ( $\$ 2.5$ million) and actual (expected) mean employee pay is $\$ 50,000(\$ 45,000)$. That is, the CEO is overpaid by $100 \%$ and employees by $11.1 \%$. Then $S P R=100, E P R=55.5$, and $U P R=45.5$. Next, consider the case where both the CEO and employees are overpaid, but the CEO is overpaid less in percentage terms: Actual (expected) CEO pay is $\$ 5$ million ( $\$ 4.5$ million) and actual (expected) mean employee pay is $\$ 50,000(\$ 25,000)$. That is, the CEO is overpaid by $11.1 \%$ and employees by $100 \%$. Then $S P R=100, E P R=185$, and $U P R=-80$. $U P R$ will be 0 when CEO and employees are overpaid (or underpaid) by the same percentage.

${ }^{35}$ Prior literature has shown that excess CEO pay is negatively related to firm performance (e.g., Core et al. 1999).
} 
the numerator and denominator plays an important role in this relation and providing further evidence that $L n U P R$ is capturing, in part, the concept of pay fairness, consistent with prediction 2. These results also suggest that employees take into account economic factors determining pay when reacting to how compensation is distributed within the firm.

Case 4 (firms with underpaid CEOs and overpaid employees) is also of interest. In Column (1), the coefficient is negative (although not significant at conventional levels), suggesting that these firms have weaker future performance. The coefficient in Column (2) is positive and significant, providing evidence that, within these firms, performance increases as the (negative) $U P R$ increases (i.e., when UPR gets closer to zero because CEOs are underpaid less and/or employees are overpaid less). In other words, as compensation moves closer to the expected level based on economic determinants, performance increases. This result is consistent with the conjecture in section 5.3.2 that employees are at least partly aware of the economic factors that determine compensation and disparity, and provides evidence that performance benefits from fairer pay. ${ }^{36}$

To further allay concerns that the relation between $L n U P R$ and performance is entirely driven by either excess CEO pay, as shown in Core etl al. (1999), or executive pay disparity, as shown in Bebchuk et al. (2011), in untabulated tests, I rerun my main regressions and include both excess CEO pay (calculated as CEO pay - explained CEO pay from Equation (2)) and the CEO pay slice (CEO total pay divided by the total pay of the top five executives) as controls. The coefficient on $L n U P R$ remains negative and significant when these controls are included.

\subsection{Summary}

\footnotetext{
${ }^{36}$ While the coefficients for Case 2 are both negative and marginally significant, it is difficult to interpret this result since $U P R$ is negative for Case 2 firms.
} 
The results in Section 5 suggest that pay disparity does impact firm performance, but that this effect is complex. When pay disparity (a high pay ratio) is the result of economic factors ( $L n$ $E P R$ ), performance increases, which is consistent with Tournament Theory and is perhaps a better way to measure tournament incentives than examining raw pay disparity: Unlike raw compensation, which may include pay due to factors like rents and favoritism, explained compensation is more directly related to observable factors. Therefore, employees are more certain of the compensation that will come with increased effort (Lazear and Rosen 1981). When pay disparity is not justified by economic factors ( $L n U P R)$, perhaps reflecting how rents are distributed between executives and employees, performance suffers (Akerlof and Yellen 1990). In Section 6, I further examine how the relation between $L n U P R$ and performance varies in the cross-section depending on firm characteristics.

\section{Interpreting the negative relation between unexplained pay disparity and performance}

\subsection{Using corporate governance quality to identify 'bad' pay disparity}

Section 5 documents a negative relation between unexplained pay disparity (Ln UPR) and firm performance. As noted above, one interpretation is that the unexplained portion of pay disparity reflects an unfair distribution of rents within the firm. If this is the case, I would expect a more pronounced negative relation between $L n U P R$ and performance when the quality of corporate governance is poor. Put differently, since there is measurement error in my estimate of $L n U P R$, one may view the subset of firms with high $L n U P R$ and poor governance quality as capturing the portion of unexplained pay disparity more likely to reflect inequity in rents distribution, and, thus, more likely to negatively affect performance.

In Table 10, I use two proxies for governance: Eindex, the Entrenchment Index of the CEO's insulation from market discipline (Bebchuk et al. 2009), and InstOwn, the shares owned by institutional investors scaled by total shares outstanding, which an extensive literature has 
identified as an effective monitoring proxy. In particular, in Column (1), I include two additional variables, High Eindex, which is equal to 1 if a firm's Entrenchment Index is above the median, and 0 otherwise, and the interaction between Ln UPR and High Eindex. Consistent with my prediction, I find that the coefficient on the interaction term, -0.0036 , is negative and significant. In Column (2), I include an indicator equal to 1 if InstOwn is less than the median, and 0 otherwise. The coefficient on interaction term at -0.0010 is negative as predicted, though not statistically significant at conventional levels ( $t$ statistic of -1.39). Overall, these results are consistent with Prediction 3.

\subsection{How does unexplained pay disparity affect performance? The employee turnover channel}

Having provided evidence that unexplained pay disparity has a negative effect on performance, it is natural to examine why this relation occurs (i.e., what is the channel through which $L n U P R$ affects performance?). Equity Theory suggests that employees will seek retribution for perceived underpayments by taking actions such as shirking or leaving the firm (Akerlof and Yellen 1990). I focus on one particular mechanism: employee turnover. Employees dissatisfied with perceived pay inequity are more likely to leave the firm. Replacing these employees is costly (search costs, training new employees, short-term decline in productivity) and may have a negative impact on performance. Table 11 tests how two proxies for employee satisfaction (Fortune and Just fair pay) and two proxies for turnover risk, Turnover and a measure of industry labor market tightness, impact the relation between Ln UPR and performance.

In Column (1) of Panel A, I create an indicator, No Fortune, equal to 1 if a firm is not included on Fortune's “100 Best Companies to Work" list. In Column (2), I create an indicator equal to 1 if a firm has a Just fair pay score below the median, where Just fair pay is defined as above. In both columns, the coefficient on the interaction between $L n U P R$ and the indicator for 
low satisfaction is negative and significant at $1 \%$, providing evidence that the negative relation between Ln UPR and performance is stronger when employees are dissatisfied, supporting prediction 4a.

In Panel B, I examine whether this relation is also stronger when firms face greater labor market risks. In Column (1) I examine firm-level year-ahead Turnover, defined as above. I create an indicator, High Turn, equal to 1 if a firm's Turnover is greater than the sample median, and 0 otherwise. Consistent with Prediction 4b, the coefficient on the interaction between UPR and High Turn, -0.0023 , is negative and significant at the $1 \%$ level, providing evidence for a potential channel through which greater UPR leads to weaker performance: increased future turnover. In Column (2), I examine Labor market tightness, a proxy for the mobility of workers, measured at the industry level. Specifically, using BLS's Job Openings and Labor Turnover Survey (JOLTS) database, I calculate Labor market tightness as the industry-year rate of voluntary quits and job openings divided by the rate of layoffs and other separations. It is more likely that employees will quit in response to pay disparity (i.e., turnover risk is higher) when it is easier for them to get another job (Labor market tightness is higher). I construct an indicator, High LabMark, equal to 1 if a firm is in an industry where Labor market tightness is greater than the median, and 0 otherwise. The coefficient on the interaction between UPR and High LabMark, -0.0036, is negative and significant at the 5\% level suggesting that the negative relation between UPR and performance is more pronounced for firms in tighter labor markets (i.e., when employees have better outside options), consistent with Prediction 4c.

\section{Conclusion}

The results in this paper describe a complex relation between firm-level pay disparity and firm performance. While there is no evidence of a statistically significant relation between 
performance and disparity when disparity is broadly defined, narrowing the definition provides insights into how the structure of compensation within firms relates to firm performance. The components of compensation that are explained by economic factors create disparity that is positively related to firm performance, while disparity created by unexplained compensation is negatively related to performance, as well as to employee satisfaction. In addition, the negative relation between unexplained disparity and performance is driven largely by firms where the CEO is overpaid and employees are underpaid, providing evidence that this measure of unexplained disparity $(U P R)$ is an effective proxy for pay fairness and that employees take into account the economic determinants of compensation when reacting to pay disparity. This negative relation also is more pronounced for firms with weaker corporate governance, lower employee satisfaction, higher future turnover, and greater labor market risk.

That different types of pay disparity can have different effects on firms should be of interest to regulators and investors, given that the SEC will begin requiring firms to disclose the CEO pay ratio beginning in 2018. This paper lends credence to a concern of the pay ratio disclosure, that interpreting the ratio in a meaningful way will be challenging. As prior research and media reports suggest, financial statement users may focus on the raw ratios without putting them into economic context (Globalist 2013; Mas 2016).

This study benefits from access to detailed data that allow me to put the CEO pay ratio into context to provide a deep understanding of what drives disparity. These data are not available to most financial statement users. Therefore, the onus for preventing the misuse of pay ratios once they are disclosed falls to the firm. The final CEO pay ratio rule allows firms to provide explanations of how the ratio is created, and the results in this paper suggest that firms may be best 
served by offering detailed information to investors about the economic justifications for their ratios. 


\section{References}

Abowd, J., Kramarz, F., Margolis, D., 1999. High wage workers and high wage firms. Econometrica 67(2), 251-333.

Agrawal, A., Matsa, D., 2013. Labor unemployment risk and corporate financing decisions. Journal of Financial Economics 107(2), 449-470.

Akerlof, G., Yellen, J., 1990. The Fair Wage-Effort Hypothesis and unemployment. The Quarterly Journal of Economics 105(2), 255-283.

Ballou, B., Godwin, N., Shortridge, R., 2003. Firm value and employee attitudes on workplace quality. Accounting Horizons 17(4), 329-341.

Barth, E., Bryson, A., Davis, J., Freeman, R., 2014. It's where you work: Increases in earnings dispersion across establishments and individuals in the U.S. Working paper, National Bureau of Economic Research.

Bebchuk, L., Cohen, A., Ferrell, A., 2009. What matters in corporate governance. Review of Financial Studies 22, 783-827.

Bebchuk, L., Cremers, K.J., Peyer, U., 2011. The CEO pay slice. Journal of Financial Economics 102, 199-221.

Berk, J., Stanton, R., Zechner, J., 2010. Human capital, bankruptcy, and capital structure. The Journal of Finance 65(3), 891-926.

Bloom, M., Michel, J., 2002. The relationships among organizational context, pay dispersion, and managerial turnover. The Academy of Management Journal 45(1), 33-42.

Bova, F., Kolev, K., Thomas, F., Zhang, X.F., 2015. Non-executive employee ownership and corporate risk. The Accounting Review 90(1), 115-145.

Card, D., Mas, A., Moretti, E., Saez, E., 2012. Inequality at work: The effect of peer salaries on job satisfaction. The American Economic Review 102(6), 2981-3003.

Carter, M., Lynch, L., 2004. The effect of stock option repricing on employee turnover. Journal of Accounting and Economics 37(1), 91-112.

Chemmanur, T., Cheng, Y., Zhang, T., 2013. Human capital, capital structure, and employee pay: An empirical analysis. Journal of Financial Economics 110, 478-502.

Cobb, J.A., 2016. How firms shape income inequality: Stakeholder power, executive decision making, and the structuring of employment relationships. Academy of Management Review 41(2), 324-348. 
Core, J., Holthausen, R., Larcker, D., 1999. Corporate governance, chief executive officer compensation, and firm performance. Journal of Financial Economics 51, 371-406.

Cowherd, D., Levine, D., 1992. Product quality and pay equity between lower-level employees and top management: An investigation of distributive justice theory. Administrative Science Quarterly 37(2), 302-320.

Crawford, S., Nelson, K., Rountree, B., 2016. Mind the gap: CEO-employee pay ratios and shareholder Say on Pay votes. Working paper, University of Houston and Rice University.

Dornstein, M., 1988. Wage reference groups and their determinants: A study of blue-collar and white-collar employees in Israel. Journal of Occupational Psychology 61, 221-235.

Downes, P., Choi, D., 2014. Employee reactions to pay dispersion: A typology of existing research. Human Resource Management Review 24, 53-66.

Edmans, A., 2011. Does the stock market fully value intangibles? Employee satisfaction and equity prices. Journal of Financial Economics 101, 621-640.

Faleye, O., Reis, E., Venkateswaran, A., 2013. The determinants and effects of CEO-employee pay ratios. Journal of Banking \& Finance 37, 3258-3272.

Garrett, J., Hoitash, R., Prawitt, D., 2014. Trust and financial reporting quality. Journal of Accounting Research 52(5), 1087-1125.

Gipper, B., 2016. Assessing the effects of mandated compensation disclosures. Working paper, Stanford University.

Globalist, 2013. Just the facts: CEOs and the rest of us. The Globalist, November 13. Accessed December 12, 2015 from http://www.theglobalist.com/just-facts-ceos-rest-us.

Goergen, M., Chahine, S., Brewster, C., Wood, G., 2013. Trust, owner rights, employee rights and firm performance. Journal of Business Finance and Accounting 40(5), 589-619.

Graham, J., Harvey, C., Popadak, J., Rajgopal, S., 2017. Corporate culture: Evidence from the field. Working paper, Duke University and Columbia University.

Groshen, E., 1991a. Five reasons why wages vary among employers. Industrial Relations 30, 350381.

Groshen, E., 1991b. Sources of intra-industry wage dispersion: How much do employers matter? The Quarterly Journal of Economics 106(3), 869-884.

Gupta, N., Conroy, S., Delery, J., 2012. The many faces of pay variation. Human Resource Management Review 22, 100-115. 
Handwerker, E., Mason, L., 2014. Assessing the usefulness of Census Bureau multi-establishment data to facilitate linking firms with establishments in BLS microdata. JSM Proceedings, 43844391.

Harsen, B., Ward, M., Buyniski, T., 2010. Dodd-Frank Act: The importance of putting CEO pay multiples into context. Global Equity Organization. Available from http://www.globalequity.org/geo/node/2360.

Heyman, F., 2005. Pay inequality and firm performance: Evidence from matched employeremployee data. Applied Economics 37(11), 1313-1327.

Holmstrom, B., 1979. Moral hazard and observability. The Bell Journal of Economics 10(1), 7491.

Kale, J., Reis, E., Venkateswaran, A., 2009. Rank-order tournaments and incentive alignment: The effect on firm performance. The Journal of Finance 64(3), 1479-1512.

Lazear, E., Rosen, S., 1981. Rank-order tournaments as optimum labor contracts. Journal of Political Economy 89(5), 841-864.

Lee, K., Lev, B., Yeo, G., 2008. Executive pay dispersion, corporate governance, and firm performance. Review of Quantitative Finance and Accounting 30(3), 315-338.

Lemieux, T., 2008. The changing nature of wage inequality. Journal of Population Economics 21(1), 21-48.

Main, B., O’Reilly, C., Wade, J., 1993. Top executive pay: Tournament or teamwork? Journal of Labor Economics 11(4), 606-628.

Martin, J., 1982. The fairness of earnings differentials: An experimental study of the perceptions of blue-collar workers. The Journal of Human Resources 17(1), 110-122.

Mas, A., 2016. Does pay transparency lead to pay compression? Working paper, Princeton University.

Mayer, R., Gavin, M., 2005. Trust in management and performance: Who minds the shop while the employees watch the boss? Academy of Management Journal 48(5), 874-888.

Menendez, R., 2011. Letter to the SEC. Available from http://www.menendez.senate.gov/imo/media/doc/Letter\%20to\%20SEC1-19-11.pdf.

Merz, M., Yashiv, E., 2007. Labor and the market value of the firm. The American Economic Review 97(4), 1419-1431. 
Michaels, R., Page, T.B., Whited, T., 2015. Labor and capital dynamics under financing frictions. Working paper, Federal Reserve Bank of Philadelphia, University of Houston, and University of Michigan.

Mueller, H., Ouimet, P., Simintzi, E., 2016. Within-firm pay inequality. Working paper, New York University, University of North Carolina-Chapel Hill, and University of British Columbia.

Murphy, K., 1999. Executive Compensation. In O. Ashenfelter and D. Card (Eds.). Handbook of Labor Economics, Vol. 3, Elsevier, 2485-2563.

Murphy, K., 2001. Performance standards in incentive contracts. Journal of Accounting and Economics 30, 245-278.

Nagar, V., 2002. Delegation and incentive compensation. The Accounting Review 77(2), 379-395.

Securities and Exchange Commission (SEC). 2013. Pay ratio disclosure. September 18.

Securities and Exchange Commission (SEC). 2015. Pay ratio disclosure. August 15.

Shaw, J., Gupta, N., Delery, J., 2002. Pay dispersion and workforce performance:

Moderating effects of incentives and interdependence. Strategic Management Journal 23, 491-512.

Shin, J., Kang, S., Hyun, J., Kim, B., 2015. Determinants and performance effects of executive pay multiples: Evidence from Korea. ILR Review 68(1), 53-78.

Siegel, P., Hambrick, D., 2005. Pay disparities within top management groups: Evidence of harmful effects on performance of high-technology firms. Organization Science 16(3), 259-274.

Song, J., Price, D., Guvenen, F., Bloom, N., von Wachter, T., 2015. Firming up inequality. Working paper, National Bureau of Economic Research.

Trevor, C., Reilly, G., Gerhart, B., 2012. Reconsidering pay dispersion's effect on the performance of interdependent work: Reconciling sorting and pay inequality. Academy of Management Journal 55(3), 585-610.

Wade, J., O'Reilly, C., Pollock, T., 2006. Overpaid CEOs and underpaid managers: Fairness and executive compensation. Organization Science 17(5), 527-544. 


\section{Appendix}

\begin{tabular}{ll} 
Variable & Definition \\
\hline Establishment level & Total yearly compensation/total yearly employment, measured at the end of the \\
Mean pay & Airm fiscal year \\
Tot emp & Year-ove yearly employment, measured at the end of the fiscal year \\
Ch emp & Percent of employees working in R\&D jobs \\
$R \& D$ emp pct & Indicator equal to 1 if $R \& D$ emp pct is greater than 0 \\
$R \& D$ indicator & Percent of employees working in technology jobs \\
Tech emp pct & Indicator equal to 1 if Tech emp pct is greater than 0 \\
Tech indicator & Percent of employees working in non-retail sales jobs \\
Sales emp pct & Indicator equal to 1 if Sales emp pct is greater than 0 \\
Sales indicator & Percent of employees working in retail jobs \\
Retail emp pct & Indicator equal to 1 if Retail emp pct is greater than 0 \\
Retail indicator & Percent of employees working in non-financial services jobs \\
Services emp pct & Indicator equal to 1 if Services emp pct is greater than 0 \\
Services indicator & Percent of employees working in manufacturing jobs \\
Manufact emp pct & Indicator equal to 1 if Manufact emp pct is greater than 0 \\
Manufact indicator & Indicator equal to 1 if top executives are working in the establishment \\
Exec indicator & Percent of employees with supervisory roles \\
Supervisor pct &
\end{tabular}

Macroeconomic level

Ind-region comp

College grad

Right to work

\section{Firm level}

Adj RNOA

Ln assets

BTM

Leverage

Labor productivity

Capital intensity

Lnage

CEO pay

$R \& D /$ sales

RNOA Var

Chrev

Adj ROA

Ret
Average industry-level compensation for the nearest Metropolitan (or Micropolitan) Statistical Area, from the U.S. Census Bureau

Percent of residents of nearest Metropolitan Statistical Area that hold a college degree, from the U.S. Census Bureau

Indicator equal to 1 if the establishment is located in a state that passed a "Right to Work" law for private firms

(operating income $*(1$-tax rate $)) /($ total assets - total cash) - (total liabilities - total debt)) - median two-digit SIC code RNOA, from Compustat

The natural log of total assets, from Compustat

Book value of equity/(share price * total shares outstanding), from Compustat

Total debt/total assets, from Compustat

Total sales/total employees, from Compustat

Capital expenditures/total sales, from Compustat

Natural log of (current year - first year firm appeared in CRSP)

Total CEO compensation, from Execucomp

$\mathrm{R} \& \mathrm{D}$ expense/total sales, from Compustat

Rolling five-year standard deviation of Adj RNOA

Year-over-year change in total revenue, from Compustat

Income before extraordinary items/total assets - median two-digit SIC code ROA, from Compustat

$\log (1+$ continuously compounded monthly return during the fiscal year), from CRSP 
Ret var

ROA var

Ln CEO tenure

Ln CEO age

Outside CEO

Loss

$S P R$

$E P R$

$U P R$

Emp pct

Fortune

JUST fair pay

Turnover

Labor market tightness

Eindex

InstOwn
Rolling 60-month standard deviation of returns, from CRSP

Rolling five-year standard deviation of $\operatorname{Adj} R O A$

The natural $\log$ of the number of years the CEO has held that position, from Execucomp

The natural log the CEO's age, from Execucomp

An indicator equal to 1 if the CEO was hired from outside the firm, from Execucomp

Indicator equal to 1 if net income is less than 0 , from Compustat

CEO Pay/Mean pay, from Execucomp and BLS

Expected CEO compensation/expected mean compensation, where expected compensation is calculated using the empirical models in equations (1) and (2)

$S P R-E P R$

Total employees used to calculate mean compensation from QCEW/total employees reported in Compustat

An indicator equal to 1 if a firm was included in Fortune magazine's "100 Best Places to Work" in a given year

The average of four measures of fair pay as defined by JUST Capital. The four measures are based on whether the company pays a living wage, whether it discriminates in its compensation practices, whether compensation is fair compared to others doing the same job, and the gap between CEO compensation and non-executive compensation

Cancelled options at the end of year $t+1 /$ total outstanding options at the beginning of year $\mathrm{t}$, from Compustat

(Quit rate + job opening rate)/(layoff rate + other separations rate), measured at the industry level and calculated using the BLS JOLTS database

The Entrenchment Index, as defined by Bebchuk et al. (2009)

Shares held by institutional investors/total shares outstanding, from Thomson Reuters Institutional Holdings database 
Figure 1: Merging of financial, address, and establishment data

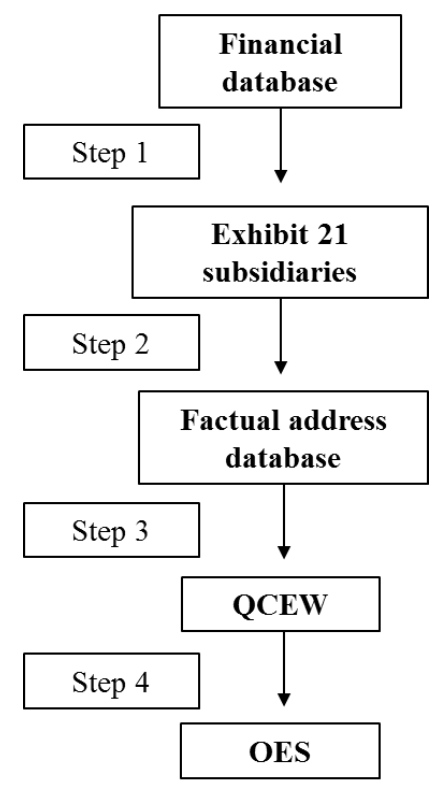

Creating a firm-level database of BLS data is challenging given the lack of firm-level identifiers (Handwerker and Mason 2014). To overcome this challenge, I collected a list of subsidiary names from the SEC's EDGAR website and merged it with financial data from Compustat, CRSP, and Execucomp. I then merged these data with Factual, a database of more than 20 million establishment addresses. Factual provides the common identifiers (name, address, geographic coordinates) to merge firm-level identifiers from the financial database with the BLS establishment database. 


\section{Table 1: Sample construction}

\begin{tabular}{|c|c|c|c|}
\hline & & Firm-years & Establishment-years \\
\hline Financial dataset & & 12,607 & \\
\hline \multirow[t]{2}{*}{ Factual } & + & & $\sim 20$ million \\
\hline & & & 550,828 \\
\hline \multirow[t]{2}{*}{ Hand check } & - & & 335,020 \\
\hline & & 11,937 & 215,808 \\
\hline$Q C E W$ merge & & 8,320 & 132,239 \\
\hline \multirow[t]{2}{*}{ Hand check } & - & & 81,663 \\
\hline & & 6,134 & 120,576 \\
\hline OES merge & & 5,208 & 104,478 \\
\hline
\end{tabular}

Table 1 reports how the sample used in this study changes with the introduction of each dataset, beginning with the full financial dataset from Compustat, CRSP, and Execucomp, and ending with the complete merge of all data from Factual, QCEW, and OES. 


\section{Table 2: The predicted relation between economic variables and establishment-level employee compensation}

\begin{tabular}{|c|c|c|c|}
\hline & Variable & $\begin{array}{l}\text { Predicted } \\
\text { sign }\end{array}$ & Explanation \\
\hline \multirow[t]{15}{*}{$\begin{array}{l}\text { Establishment } \\
\text { factors }\end{array}$} & Ch emp & + & $\begin{array}{l}\text { A proxy for establishment profitability, which is not directly available } \\
\text { from BLS. Establishments that increase employment do so as a reaction } \\
\text { to prior positive performance and in anticipation of future positive } \\
\text { performance (Merz and Yashiv 2007). }\end{array}$ \\
\hline & $R \& D$ emp pct & + & $\begin{array}{l}\text { A proxy for the need for human capital within the establishment. } \\
\text { Knowledge workers have invested significant resources in education, } \\
\text { possess valuable knowledge of the firm, and, particularly in industries } \\
\text { where technological advancement are important, should command } \\
\text { higher salaries. In addition, R\&D intensity is closely related to } \\
\text { uncertainty, so higher-level employees should be paid more and more } \\
\text { equally (Siegel and Hambrick 2005). }\end{array}$ \\
\hline & $R \& D$ indicator & + & $\begin{array}{l}\text { A measure of the presence of knowledge workers, who are expected to } \\
\text { have higher compensation as described above. }\end{array}$ \\
\hline & Tech emp pct & + & $\begin{array}{l}\text { Similar to } R \& D \text { work, I expect this measure to be positively related to } \\
\text { compensation since technology workers have specialized skills, and } \\
\text { their output can be difficult to monitor. }\end{array}$ \\
\hline & Tech indicator & + & $\begin{array}{l}\text { A measure of the presence of technology workers, who are expected to } \\
\text { have higher compensation as described above. }\end{array}$ \\
\hline & Sales emp pct & + & $\begin{array}{l}\text { Non-retail sales employees are more likely to have greater variation in } \\
\text { their compensation with pay more closely tied to firm performance. } \\
\text { When compensation is more variable, total compensation should be } \\
\text { higher. In addition, sales employees are more likely to be white collar } \\
\text { workers, demanding higher salaries. }\end{array}$ \\
\hline & Sales indicator & + & $\begin{array}{l}\text { A measure of the presence of non-retail sales workers, who are expected } \\
\text { to have higher compensation as described above. }\end{array}$ \\
\hline & Retail emp pct & - & $\begin{array}{l}\text { Retail workers are often seasonal or temporary, are less likely to receive } \\
\text { benefits, and are considered low skilled, leading to lower compensation. }\end{array}$ \\
\hline & Retail indicator & - & $\begin{array}{l}\text { A measure of the presence of retail workers, who are expected to have } \\
\text { lower compensation as described above. }\end{array}$ \\
\hline & Services emp pct & - & $\begin{array}{l}\text { Much like the retail industry, non-financial services workers are often } \\
\text { part-time and considered low skilled. }\end{array}$ \\
\hline & Services indicator & - & $\begin{array}{l}\text { A measure of the presence of non-financial service workers, who are } \\
\text { expected to have lower compensation as described above. }\end{array}$ \\
\hline & Manufact emp pct & - & $\begin{array}{l}\text { The output of manufacturing workers is easily monitored, and the skills } \\
\text { needed often require little education. In addition, these jobs are easily } \\
\text { outsourced to low-wage countries, meaning that compensation for } \\
\text { manufacturing workers faces downward pressure. }\end{array}$ \\
\hline & Manufact indicator & - & $\begin{array}{l}\text { A measure of the presence of manufacturing workers, who are expected } \\
\text { to have lower compensation as described above. }\end{array}$ \\
\hline & Exec indicator & + & $\begin{array}{l}\text { Pay structure for executives is vastly different from that for lower-level } \\
\text { employees. Firm headquarters, where most top executives are located, } \\
\text { is also expected to have a high proportion of white-collar workers. }\end{array}$ \\
\hline & Supervisor pct & + & $\begin{array}{l}\text { A proxy for monitoring. Agency Theory predicts that there exists a } \\
\text { tradeoff between monitoring and compensation, so a lower ratio may } \\
\text { lead to higher compensation (Holmstrom 1979). In addition, } \\
\text { Tournament Theory predicts that managers will make more than their } \\
\text { subordinates (Lazear and Rosen 1981). }\end{array}$ \\
\hline
\end{tabular}



Macroeconomic Ind-region comp +
factors

Col grad

Right to work

Firm Ln assets

characteristics

Ln age

$R \& D /$ sales

Adj RNOA

RNOA variance

Labor productivity

Capital intensity

Leverage

$B T M$

Ch rev
Compensation levels are shaped by the labor market for employees, so the compensation at similar establishments in the same region should be positively related to establishment compensation.

A proxy for the skill level of the local population. A more highly educated population is likely to work in more highly-skilled professions.

"Right to Work" states have passed laws that have been shown to weaken union influence. Union representation has been shown to increase compensation and reduce inequality (e.g., Cowherd and Levine 1992; Lemieux 2008).

+ Larger firms have greater resources to attract high-skilled workers, leading to a positive relation between compensation and firm size, and representing both the ability to pay and the firm's employment needs.

+/- Younger firms are more likely to face capital constraints, limiting their ability to pay employees. Alternatively, because they are more risky and need to attract high-quality employees, they may be forced to pay more (Shin et al. 2015).

$+\quad$ A proxy for the research intensity of the firm. Research-intensive firms are more dependent on human capital, and the market for research employees is likely competitive, meaning that the relation between research intensity and compensation should be positive.

$+\quad \operatorname{Adj} R N O A$ is a measure of the operating profitability of the firm, and more profitable firms have the ability to pay more, thereby attracting highly skilled workers (e.g., Abowd et al. 1999).

$+\quad$ A proxy for firm profitability risk. Profitability risk should influence compensation in two ways. First, it should be related to the structure of compensation since greater variability makes incentive compensation more risky to the employee and costly to the firm (Holmstrom 1979). Second, greater variance may increase the likelihood of layoffs, a risk that the firm is expected to share with its employees (Agrawal and Matsa 2013).

$+\quad$ Labor productivity may be a proxy for employee bargaining power in that labor-productive firms are more dependent on their employees, leading to higher compensation.

+/- $\quad$ More capital intensive firms may be less reliant on employees, leading to decreases in compensation. Alternatively, capital intensive firms may need employees with specialized skills, leading to higher compensation. Since interest payments directly impact a firm's ability to make its payroll, higher leverage may be negatively associated with compensation. Alternatively, firms with higher leverage are at more risk of bankruptcy, potentially requiring risk payments to employees (Berk, Stanton, and Zechner 2010; Chemmanur, Cheng, and Zhang 2013).

The book-to-market ratio is negatively correlated with profitability, and more profitable firms pay more (Abowd et al. 1999). In addition, growth opportunities lead firms to delegate more responsibility to lower-level employees and provide them with stronger incentives (Nagar 2002).

Firms are likely to base performance pay on accounting numbers, and revenue represents income to the firm to be distributed among stakeholders (Murphy 2001).

Table 2 describes the predicted relation between Mean pay, the mean establishment-level compensation, and establishment-, macroeconomic-, and firm-level variables expected to influence Mean pay. All variables are defined in the Appendix. 
Table 3: Comparing the BLS sample and other Execucomp firms

Panel A: Comparison of firm-level characteristics

\begin{tabular}{lccccc} 
& \multicolumn{4}{c}{ Sample } & \multicolumn{3}{c}{ Other Execucomp firms } \\
\hline Variable & $n$ & Mean & $n$ & Mean & Difference \\
\hline Adj $R$ NOA (\%) & 5,082 & 1.46 & 7,525 & 0.60 & $0.86^{* * * *}$ \\
Assets & 5,082 & 15,424 & 7,525 & 13,490 & 1,934 \\
BTM & 5,082 & 0.53 & 7,525 & 0.57 & $-0.04^{* * *}$ \\
Leverage & 5,082 & 0.68 & 7,525 & 0.83 & $-0.15^{* * *}$ \\
Labor productivity & 5,082 & 441.8 & 7,525 & 525.6 & $-83.80^{* * *}$ \\
Capital intensity & 5,082 & 48.59 & 7,525 & 59.32 & $-10.73^{* * *}$ \\
Age & 5,082 & 29.46 & 7,525 & 24.13 & $5.33^{* * *}$ \\
CEO pay & 5,082 & $5,814.3$ & 7,525 & $4,893.3$ & $921^{* * *}$ \\
RNOA var & 5,082 & 0.17 & 7,525 & 0.30 & $-0.13^{* * *}$ \\
R\&D/sales & 5,082 & 0.03 & 7,525 & 0.03 & $0.00^{* * *}$ \\
Ch rev & 5,082 & 0.08 & 7,525 & 0.08 & 0.00
\end{tabular}


Panel B: Industry composition

\begin{tabular}{lcc} 
Industry & \% of sample & $\%$ of other Execucomp firms \\
\hline Food & $3.77 \%$ & $2.80 \%$ \\
Mining and minerals & $1.28 \%$ & $0.97 \%$ \\
Oil and petroleum products & $3.87 \%$ & $4.16 \%$ \\
Textiles, apparel, and footwear & $2.11 \%$ & $1.73 \%$ \\
Consumer durables & $1.58 \%$ & $2.07 \%$ \\
Chemicals & $3.32 \%$ & $1.95 \%$ \\
Consumer goods & $3.22 \%$ & $4.16 \%$ \\
Construction and materials & $3.81 \%$ & $3.26 \%$ \\
Steel works & $1.22 \%$ & $1.40 \%$ \\
Fabricated products & $0.97 \%$ & $0.78 \%$ \\
Machinery and business equipment & $20.92 \%$ & $11.37 \%$ \\
Automobiles & $1.34 \%$ & $1.90 \%$ \\
Transportation & $4.68 \%$ & $4.11 \%$ \\
Utilities & $2.98 \%$ & $5.82 \%$ \\
Retail stores & $7.76 \%$ & $6.59 \%$ \\
Financials & $7.34 \%$ & $18.35 \%$ \\
Other & $29.82 \%$ & $28.58 \%$
\end{tabular}

Table 3 presents descriptive statistics for the firm-year observations in my sample and the firm-years observations for the other firms in Execucomp for the 2006-2013 period. Panel A compares the mean values of the firm-level characteristics used in this study, with the differences between the two samples reported in the last column. $* * *$ indicates statistically significant differences at the $1 \%$ confidence level. Panel B reports the percent of firms in each industry, where industry is defined as Fama-French 17 industry portfolios. All variables are defined in the Appendix. Continuous variables are winsorized at $1 \%$ and $99 \%$. 


\section{Table 4: Establishment-year descriptive statistics}

Panel A: Summary statistics

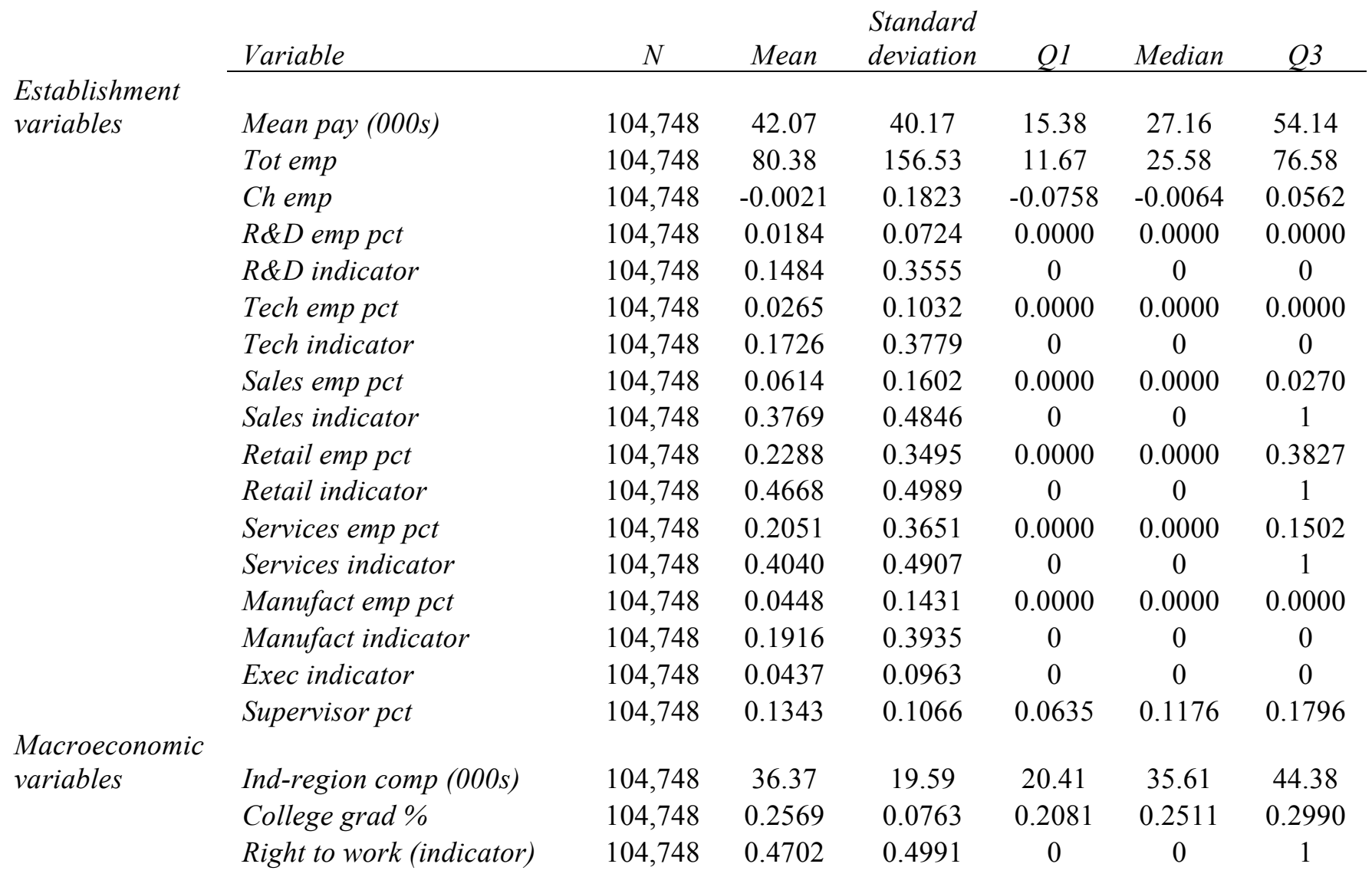


Panel B: Industry composition of establishments

\begin{tabular}{lc}
\multicolumn{1}{c}{ Industry } & \% of sample \\
\hline Food & $1.37 \%$ \\
Mining and minerals & $0.69 \%$ \\
Oil and petroleum products & $1.23 \%$ \\
Textiles, apparel, and footwear & $0.74 \%$ \\
Consumer durables & $0.32 \%$ \\
Chemicals & $1.27 \%$ \\
Consumer goods & $0.64 \%$ \\
Construction and materials & $2.23 \%$ \\
Steel works & $0.22 \%$ \\
Fabricated products & $0.46 \%$ \\
Machinery and business equipment & $4.52 \%$ \\
Automobiles & $1.35 \%$ \\
Transportation & $2.97 \%$ \\
Utilities & $1.14 \%$ \\
Retail stores & $42.77 \%$ \\
Financials & $13.65 \%$ \\
Other & $24.43 \%$
\end{tabular}

Panel C: Mean pay by establishment type

\begin{tabular}{lccc} 
& \multicolumn{2}{c}{ Mean pay (in 000s) } & \\
\cline { 2 - 3 } Variable & var $=1$ & var $=0$ & Difference \\
\hline R\&D indicator & 85.45 & 34.52 & $50.93^{* * *}$ \\
Tech indicator & 83.01 & 33.54 & $49.47^{* * *}$ \\
Sales indicator & 58.80 & 31.96 & $26.84^{* * *}$ \\
Retail indicator & 32.34 & 50.60 & $-18.26^{* * *}$ \\
Services indicator & 26.12 & 52.89 & $-26.77^{* * *}$ \\
Manufact indicator & 48.89 & 40.46 & $8.43^{* * *}$ \\
Exec indicator & 74.85 & 41.77 & $33.08^{* * *}$
\end{tabular}


Panel D: Correlation matrix

\begin{tabular}{|c|c|c|c|c|c|c|c|c|c|c|c|c|c|c|}
\hline & 1 & 2 & 3 & 4 & 5 & 6 & 7 & 8 & 9 & 10 & 11 & 12 & 13 & 14 \\
\hline 1. Mean pay & & -0.00 & $0.47^{*}$ & $0.46^{*}$ & $0.49^{*}$ & $0.48^{*}$ & $0.45^{*}$ & $0.41 *$ & $-0.33^{*}$ & $-0.22 *$ & $-0.41^{*}$ & $-0.49^{*}$ & $0.21^{*}$ & $0.19^{*}$ \\
\hline 2. Ch emp & 0.00 & & $-0.03 *$ & $-0.03 *$ & $-0.03 *$ & $-0.03 *$ & $-0.02 *$ & $-0.02 *$ & $0.01^{*}$ & $0.01^{*}$ & $0.02 *$ & $0.03^{*}$ & $-0.01 *$ & $-0.01^{*}$ \\
\hline 3. $R \& D$ eтp pct & $0.38^{*}$ & -0.01 & & $0.70^{*}$ & $0.57^{*}$ & $0.57^{*}$ & $0.19 *$ & $0.22 *$ & $-0.24 *$ & $-0.17 *$ & $-0.11^{*}$ & $-0.18^{*}$ & $0.34 *$ & $0.31^{*}$ \\
\hline 4. $R \& D$ indicator & $0.45^{*}$ & $-0.03 *$ & $0.61 *$ & & $0.57^{*}$ & $0.58^{*}$ & $0.19 *$ & $0.23 *$ & $-0.23 *$ & $-0.16^{*}$ & $-0.10^{*}$ & $-0.17 *$ & $0.34^{*}$ & $0.31 *$ \\
\hline 5. Tech emp pct & $0.39 *$ & $-0.01 *$ & $0.15^{*}$ & $0.29 *$ & & $0.99 *$ & $0.26^{*}$ & $0.29 *$ & $-0.21 *$ & $-0.13^{*}$ & $-0.12^{*}$ & $-0.19^{*}$ & $0.14^{*}$ & $0.13^{*}$ \\
\hline 6. Tech indicator & $0.47^{*}$ & $-0.02 *$ & $0.32 *$ & $0.58^{*}$ & $0.56^{*}$ & & $0.26^{*}$ & $0.29 *$ & $-0.21 *$ & $-0.12 *$ & $-0.12 *$ & $-0.19 *$ & $0.17^{*}$ & $0.16^{*}$ \\
\hline 7. Sales emp pct & $0.33^{*}$ & $0.01 *$ & $-0.02 *$ & $0.01^{*}$ & $0.02 *$ & $0.04 *$ & & $0.96^{*}$ & $-0.02 *$ & $0.13^{*}$ & $-0.18^{*}$ & $-0.26^{*}$ & $0.10^{*}$ & $0.12 *$ \\
\hline 8. Sales indicator & $0.32 *$ & $-0.02 *$ & $0.08^{*}$ & $0.23^{*}$ & $0.15^{*}$ & $0.29 *$ & $0.49 *$ & & $0.01 *$ & $0.16^{*}$ & $-0.10^{*}$ & $-0.20 *$ & $0.19^{*}$ & $0.21 *$ \\
\hline 9. Retail emp pct & $-0.35 *$ & 0.00 & $-0.16^{*}$ & $-0.26^{*}$ & $-0.16^{*}$ & $-0.25^{*}$ & $-0.17^{*}$ & $-0.18^{*}$ & & $0.94 *$ & $-0.11^{*}$ & $-0.18 *$ & $-0.04 *$ & $-0.01 *$ \\
\hline 10. Retail indicator & $-0.23 *$ & $0.01 *$ & $-0.16^{*}$ & $-0.16^{*}$ & $-0.11^{*}$ & $-0.13^{*}$ & $0.02 *$ & $0.15^{*}$ & $0.70^{*}$ & & $-0.04 *$ & $-0.13^{*}$ & $0.02 *$ & $0.05^{*}$ \\
\hline 11. Services emp pct & $-0.33 *$ & 0.00 & $-0.11 *$ & $-0.10^{*}$ & $-0.13^{*}$ & $-0.11 *$ & $-0.25^{*}$ & $-0.09 *$ & $-0.19 *$ & $-0.05^{*}$ & & $0.95^{*}$ & $0.14^{*}$ & $0.16^{*}$ \\
\hline 12. Services indicator & $-0.35 *$ & $0.02 *$ & $-0.14 *$ & $-0.22 *$ & $-0.14 *$ & $-0.24 *$ & $-0.20 *$ & $-0.35^{*}$ & $-0.28 *$ & $-0.29 *$ & $0.68^{*}$ & & $0.02 *$ & $0.04 *$ \\
\hline 13. Manufact emp pct & $0.12 *$ & $-0.02 *$ & $0.12 *$ & $0.38^{*}$ & $-0.05^{*}$ & $0.18^{*}$ & $-0.08^{*}$ & $0.06^{*}$ & $-0.18^{*}$ & $-0.15^{*}$ & $-0.02 *$ & $-0.16^{*}$ & & $0.99 *$ \\
\hline 14. Manufact indicator & $0.08^{*}$ & $-0.02 *$ & $0.15^{*}$ & $0.32^{*}$ & $-0.04 *$ & $0.16^{*}$ & $-0.11 *$ & $0.21 *$ & $-0.12 *$ & $0.06^{*}$ & $0.17^{*}$ & $-0.19 *$ & $0.64 *$ & \\
\hline 15. Exec indicator & $0.08^{*}$ & -0.00 & $0.02 *$ & $0.04 *$ & $0.01 *$ & $0.03 *$ & $0.01 *$ & $0.03 *$ & $-0.03 *$ & $-0.03 *$ & $-0.03 *$ & $-0.03 *$ & $0.00^{*}$ & $0.01 *$ \\
\hline 16. Supervisor pct & $0.11^{*}$ & 0.00 & $-0.02 *$ & -0.00 & $-0.03 *$ & 0.00 & $0.01 *$ & $0.07 *$ & $0.13^{*}$ & $0.11^{*}$ & $-0.20^{*}$ & $-0.14 *$ & $-0.06^{*}$ & $-0.08^{*}$ \\
\hline 17. Ind-region comp & $0.50 *$ & $-0.02 *$ & $0.23 *$ & $0.30^{*}$ & $0.29 *$ & $0.35^{*}$ & $0.21 *$ & $0.21 *$ & $-0.36^{*}$ & $-0.25^{*}$ & $-0.21^{*}$ & $-0.12 *$ & $0.06^{*}$ & $-0.02 *$ \\
\hline 18. College grad & $0.01 *$ & 0.00 & $0.03 *$ & $0.05^{*}$ & $0.07 *$ & $0.05^{*}$ & -0.00 & -0.00 & $-0.02 *$ & $-0.01 *$ & $0.01 *$ & $0.00^{*}$ & $0.03 *$ & $0.03 *$ \\
\hline 19. Right to work & $-0.02 *$ & 0.00 & $-0.03 *$ & $-0.02 *$ & $-0.02 *$ & $-0.02 *$ & 0.00 & $-0.03 *$ & $0.01^{*}$ & $0.01 *$ & $-0.01 *$ & -0.01 & -0.00 & $-0.03 *$ \\
\hline 20. Ln assets & $0.21 *$ & $-0.02 *$ & $0.03 *$ & $0.06^{*}$ & $0.07 *$ & $0.12 *$ & $0.12 *$ & $0.20 *$ & $-0.26^{*}$ & $-0.11 *$ & $-0.09^{*}$ & $-0.14 *$ & $-0.06^{*}$ & $-0.02 *$ \\
\hline 21. Ln age & $0.17 *$ & $-0.01^{*}$ & $0.11^{*}$ & $0.15^{*}$ & $0.07^{*}$ & $0.11^{*}$ & $0.09 *$ & $0.13 *$ & $-0.13 *$ & $-0.03 *$ & $-0.14^{*}$ & $-0.18^{*}$ & $0.14^{*}$ & $0.19 *$ \\
\hline 22. $R \& D /$ sales & $0.42 *$ & $0.01 *$ & $0.35^{*}$ & $0.35^{*}$ & $0.39^{*}$ & $0.35^{*}$ & $0.17^{*}$ & $0.17 *$ & $-0.17 *$ & $-0.11 *$ & $-0.13^{*}$ & $-0.14 *$ & $0.13^{*}$ & $0.10^{*}$ \\
\hline 23. Adj RNOA & 0.00 & $0.02 *$ & $0.05^{*}$ & $0.01^{*}$ & $0.04 *$ & 0.00 & $-0.03 *$ & $-0.12 *$ & $-0.02 *$ & $-0.07 *$ & $0.07^{*}$ & $-0.14^{*}$ & $-0.02 *$ & $-0.05^{*}$ \\
\hline 24. $R N O A$ variance & $0.09 *$ & $0.01 *$ & $0.04 *$ & $0.04 *$ & $0.10^{*}$ & $0.08^{*}$ & $0.05^{*}$ & $0.03 *$ & $0.03 *$ & $0.02 *$ & $-0.06^{*}$ & $-0.07 *$ & $-0.01 *$ & $-0.01 *$ \\
\hline 25. Labor productivity & $0.37 *$ & -0.00 & $0.20^{*}$ & $0.22 *$ & $0.09 *$ & $-0.17 *$ & $0.14 *$ & $0.15^{*}$ & $-0.08 *$ & $-0.03 *$ & $-0.22 *$ & $-0.28 *$ & $0.11^{*}$ & $0.13^{*}$ \\
\hline 26. Capital intensity & $-0.02 *$ & $-0.02 *$ & $0.01 *$ & $0.04 *$ & $0.01 *$ & $0.04 *$ & $0.02 *$ & $0.11 *$ & 0.00 & $0.03 *$ & $-0.08^{*}$ & $-0.22 *$ & $0.07 *$ & $0.10^{*}$ \\
\hline 27. Leverage & $0.03^{*}$ & $-0.02 *$ & $-0.03 *$ & $-0.01 *$ & $-0.03^{*}$ & 0.00 & $0.03 *$ & $0.03 *$ & $-0.17 *$ & $-0.10^{*}$ & $0.01^{*}$ & $0.05^{*}$ & $-0.02 *$ & $-0.03^{*}$ \\
\hline 28. BTM & $0.06^{*}$ & $-0.06^{*}$ & $-0.01 *$ & $0.04 *$ & $-0.01 *$ & $0.06^{*}$ & $0.09 *$ & $0.14 *$ & $0.02 *$ & $0.01^{*}$ & $-0.23^{*}$ & $-0.29 *$ & $0.03 *$ & $0.01 *$ \\
\hline 29. Ch rev & $0.04 *$ & $0.06^{*}$ & 0.00 & -0.00 & $0.01 *$ & $0.01 *$ & $0.04 *$ & $0.02 *$ & $-0.02 *$ & $-0.01 *$ & $-0.03 *$ & $-0.01 *$ & $-0.01 *$ & -0.01 \\
\hline
\end{tabular}




\begin{tabular}{|c|c|c|c|c|c|c|c|c|c|c|c|c|c|c|c|}
\hline & 15 & 16 & 17 & 18 & 19 & 20 & 21 & 22 & 23 & 24 & 25 & 26 & 27 & 28 & 29 \\
\hline 1. Mean pay & $0.07 *$ & $0.03 *$ & $0.54 *$ & $-0.04 *$ & $-0.02 *$ & $0.17^{*}$ & $0.19^{*}$ & $0.41 *$ & 0.00 & $0.03 *$ & $0.67^{*}$ & $0.08 *$ & $0.07 *$ & $0.21 *$ & $0.02 *$ \\
\hline 2. Ch emp & 0.00 & $0.01 *$ & $-0.01 *$ & 0.00 & $0.01 *$ & $-0.03 *$ & -0.00 & $-0.03 *$ & $0.04 *$ & $0.02 *$ & $-0.03 *$ & $-0.04 *$ & $-0.03 *$ & $-0.08 *$ & $0.11 *$ \\
\hline 3. $R \& D$ emp pct & $0.03 *$ & -0.00 & $0.28^{*}$ & $0.04 *$ & $-0.02 *$ & $0.08^{*}$ & $0.17^{*}$ & $0.43^{*}$ & $0.01 *$ & $0.08^{*}$ & $0.32 *$ & 0.00 & -0.00 & $0.07 *$ & 0.00 \\
\hline 4. $R \& D$ indicator & $0.03 *$ & -0.01 & $0.28 *$ & $0.04 *$ & $-0.02 *$ & $0.08^{*}$ & $0.17 *$ & $0.42 *$ & -0.00 & $0.08^{*}$ & $0.32 *$ & $0.01 *$ & -0.00 & $0.08 *$ & 0.00 \\
\hline 5. Tech emp pct & $0.03 *$ & -0.01 & $0.33 *$ & $0.04 *$ & $-0.02 *$ & $0.13^{*}$ & 0.11 & $0.40^{*}$ & -0.01 & $0.09 *$ & $0.31 *$ & $0.05 *$ & $-0.01^{*}$ & $0.08 *$ & 0.00 \\
\hline 6. Tech indicator & $0.03 *$ & $-0.01 *$ & $0.33 *$ & $0.04 *$ & $-0.01 *$ & $0.13^{*}$ & $0.11 *$ & $0.39 *$ & $-0.01 *$ & $0.08^{*}$ & $0.31 *$ & $0.05 *$ & -0.00 & $0.09 *$ & 0.00 \\
\hline 7. Sales emp pct & $0.02 *$ & $0.10^{*}$ & $0.28 *$ & $-0.01 *$ & $-0.02 *$ & $0.09 *$ & $0.09 *$ & $0.17^{*}$ & $-0.15^{*}$ & $0.03 *$ & $0.36^{*}$ & $0.12 *$ & $0.01 *$ & $0.16^{*}$ & $0.01 *$ \\
\hline 8. Sales indicator & $0.02 *$ & $0.09 *$ & $0.22 *$ & $-0.00 *$ & $-0.02 *$ & $0.12 *$ & $0.10^{*}$ & $0.14^{*}$ & $-0.16^{*}$ & $0.01 *$ & $0.34 *$ & $0.13^{*}$ & $0.03 *$ & $0.17 *$ & 0.00 \\
\hline 9. Retail emp pct & $-0.03 *$ & $0.18^{*}$ & $-0.38^{*}$ & $-0.01 *$ & $0.01 *$ & $-0.15^{*}$ & $-0.06^{*}$ & $-0.34 *$ & -0.00 & $-0.06^{*}$ & -0.00 & $0.21 *$ & $-0.26^{*}$ & $0.11 *$ & $0.01 *$ \\
\hline 10. Retail indicator & $-0.02 *$ & $0.16^{*}$ & $-0.29 *$ & -0.01 & $0.01 *$ & $-0.08 *$ & $-0.02 *$ & $-0.29 *$ & $-0.04 *$ & $0.04 *$ & $0.06^{*}$ & $0.19 *$ & $-0.19 *$ & $0.10 *$ & $0.02 *$ \\
\hline 11. Services emp pct & $-0.03 *$ & $-0.17^{*}$ & -0.2 & $0.01 *$ & -0.0 & $0.07 *$ & $-0.10 *$ & -0 . & $0.07 *$ & $-0.09 *$ & $-0.39 *$ & -0 & $0.19^{*}$ & -0 . & $0.01 *$ \\
\hline 12. Services indicator & $-0.03 *$ & $-0.18^{*}$ & $-0.22 *$ & $0.01 *$ & $-0.01 *$ & $0.04 *$ & $-0.13 *$ & $-0.14^{*}$ & $0.13 *$ & $-0.09 *$ & $-0.50 *$ & $-0.23 *$ & $0.20 *$ & $-0.32 *$ & $0.01 *$ \\
\hline 13. Manufact emp pct & $0.01 *$ & $-0.08^{*}$ & $-0.01 *$ & $0.03 *$ & $-0.02 *$ & $0.06^{*}$ & $0.23 *$ & $0.17 *$ & $-0.09^{*}$ & $-0.01 *$ & $0.25^{*}$ & $0.08 *$ & $0.06^{*}$ & $0.11 *$ & $0.01 *$ \\
\hline 14. Manufact indicator & $0.01 *$ & $-0.07^{*}$ & $-0.03^{*}$ & $0.03 *$ & $-0.03 *$ & $0.08^{*}$ & $0.23 *$ & $0.14^{*}$ & $-0.10^{*}$ & $-0.02 *$ & $0.25^{*}$ & $0.08 *$ & $0.07 *$ & $0.11 *$ & $0.04 *$ \\
\hline 15. Exec indicator & & $0.08^{*}$ & $0.02 *$ & 0.001 & $0.01 *$ & $-0.02 *$ & 0.00 & $0.02 *$ & -0.00 & $-0.01 *$ & $0.03 *$ & -0.00 & $-0.01 *$ & $0.01 *$ & $0.04 *$ \\
\hline 16. Supervisor pct & $0.12 *$ & & $0.07 *$ & $-0.06^{*}$ & $0.05^{*}$ & $-0.08 *$ & $-0.02 *$ & $-0.01 *$ & $0.05^{*}$ & $-0.08 *$ & $0.08^{*}$ & $-0.02 *$ & $-0.06^{*}$ & -0.00 & $0.01 *$ \\
\hline 17. Ind-region comp & $0.03 *$ & $0.06^{*}$ & & -0.00 & $-0.06^{*}$ & $0.18^{*}$ & $0.07 *$ & $0.35^{*}$ & $-0.10^{*}$ & 0.00 & $0.41 *$ & $-0.04 *$ & $0.14^{*}$ & $0.03 *$ & $0.05 *$ \\
\hline 18. College grad & $0.01 *$ & $-0.06^{*}$ & $-0.02 *$ & & $-0.06^{*}$ & $-0.05 *$ & $0.06^{*}$ & $0.02 *$ & $0.01 *$ & $0.03 *$ & $-0.03 *$ & $0.04 *$ & -0.01 & $-0.01 *$ & $0.11 *$ \\
\hline 19. Right to work & $0.01 *$ & $0.06^{*}$ & $-0.05^{*}$ & $-0.07 *$ & & $-0.03 *$ & $0.04 *$ & $-0.04 *$ & $0.02 *$ & $-0.01 *$ & $-0.02 *$ & $0.03 *$ & $0.01 *$ & $-0.02 *$ & $0.03 *$ \\
\hline 20. Ln assets & $-0.03 *$ & $-0.04 *$ & $0.23 *$ & $-0.06^{*}$ & $-0.04 *$ & & $0.38^{*}$ & $0.14 *$ & $-0.03 *$ & $-0.07 *$ & $0.43^{*}$ & $-0.22 *$ & $0.42 *$ & $-0.01 *$ & $0.01 *$ \\
\hline 21. Ln age & -0.00 & 0.00 & $0.08 *$ & $0.03 *$ & $0.04 *$ & $0.41 *$ & & $0.11^{*}$ & $0.01 *$ & $0.07 *$ & $0.28 *$ & $-0.02 *$ & $0.15^{*}$ & $0.03 *$ & $-0.07 *$ \\
\hline 22. $R \& D /$ sales & $0.01 *$ & -0.00 & $0.27 *$ & $0.05^{*}$ & $-0.02 *$ & $-0.07 *$ & $0.04 *$ & & $0.27 *$ & $0.15^{*}$ & $0.23^{*}$ & $-0.14^{*}$ & $0.06^{*}$ & $-0.22 *$ & $0.03 *$ \\
\hline 23. Adj RNOA & -0.00 & -0.01 & $-0.04 *$ & $0.01 *$ & $0.02 *$ & $-0.06^{*}$ & $-0.04 *$ & $0.11^{*}$ & & $0.10^{*}$ & $-0.21 *$ & $-0.19^{*}$ & $-0.15^{*}$ & $-0.60 *$ & $0.15^{*}$ \\
\hline 24. $R N O A$ variance & -0.00 & $0.01 *$ & $0.06^{*}$ & $0.02 *$ & 0.00 & $-0.12 *$ & $-0.06 *$ & $0.24 *$ & $0.05^{*}$ & & $-0.02 *$ & $-0.17 *$ & $-0.08^{*}$ & $-0.11^{*}$ & $-0.07 *$ \\
\hline 25. Labor productivity & $0.03 *$ & $0.07 *$ & $0.33 *$ & $-0.01 *$ & $0.01 *$ & $0.31 *$ & $0.20^{*}$ & $0.07 *$ & $-0.06^{*}$ & $0.01 *$ & & $0.06^{*}$ & $0.12 *$ & $0.24 *$ & $0.05^{*}$ \\
\hline 26. Capital intensity & -0.00 & $-0.07 *$ & $-0.01 *$ & $0.03 *$ & 0.00 & $-0.16^{*}$ & -0.00 & $-0.05^{*}$ & $-0.21^{*}$ & $0.04 *$ & -0.00 & & $-0.13^{*}$ & $0.26^{*}$ & $-0.09 *$ \\
\hline 27. Leverage & $-0.01 *$ & $-0.01 *$ & $0.11 *$ & $-0.02 *$ & $0.03 *$ & $0.24^{*}$ & $0.12 *$ & $-0.06 *$ & $-0.07 *$ & $-0.04 *$ & $0.03^{*}$ & $-0.01 *$ & & $-0.07 *$ & $-0.08 *$ \\
\hline 28. BTM & -0.00 & 0.01 & $0.07 *$ & $-0.01 *$ & $0.01 *$ & $0.15^{*}$ & $0.06^{*}$ & $-0.11^{*}$ & $-0.26^{*}$ & $-0.04 *$ & $0.13^{*}$ & $0.27 *$ & $0.07 *$ & & $-0.23 *$ \\
\hline 29. Ch rev & $0.01 *$ & $0.04^{*}$ & $0.06^{*}$ & $0.01 *$ & -0.00 & $0.01^{*}$ & $-0.05^{*}$ & $0.02 *$ & $0.07 *$ & $0.01 *$ & $0.05^{*}$ & $-0.07^{*}$ & $0.15^{*}$ & $-0.12 *$ & \\
\hline
\end{tabular}

Table 4 presents the descriptive statistics of establishment-level variables. Panel A reports general descriptive statistics. Panel B reports the percent of establishments in each industry, where industry is defined as Fama-French 17 industry portfolios. Panel C compares the mean compensation across establishments with different workforce composition, i.e., depending on whether a certain type of employees (e.g., R\&D) are present in the establishment (see indicator variable listed on the left). Differences between mean compensations are reported in the final column. *** indicates significance at the $1 \%$ confidence level. Panel D reports Pearson (Spearman) correlations below (above) the diagonal, with * indicating significance at the 5\% confidence level. All variables are defined in the Appendix. Continuous variables are winsorized at $1 \%$ and $99 \%$. 


\section{Table 5: Modeling explained compensation}

Panel A: Establishment-level employee compensation model

\begin{tabular}{|c|c|c|c|c|c|}
\hline \multirow[b]{2}{*}{ Variable } & \multirow[b]{2}{*}{ predicted sign } & \multicolumn{4}{|c|}{ Mean pay } \\
\hline & & (1) & (2) & (3) & (4) \\
\hline \multirow[t]{2}{*}{ Ch emp } & + & $3.180 * *$ & $3.620 * * *$ & $2.736 * *$ & $3.056 * * *$ \\
\hline & & $(2.25)$ & $(2.98)$ & $(2.26)$ & $(3.06)$ \\
\hline \multirow[t]{2}{*}{$R \& D$ eтp pct } & + & $94.389 * * *$ & $86.841^{* * *}$ & $61.257^{* * *}$ & $53.356^{* * *}$ \\
\hline & & (7.97) & $(8.48)$ & $(9.14)$ & $(7.00)$ \\
\hline \multirow[t]{2}{*}{$R \& D$ indicator } & + & $11.280^{* * *}$ & $9.952 * * *$ & $9.006^{* * *}$ & $7.046 * * *$ \\
\hline & & $(6.62)$ & $(6.38)$ & (6.17) & $(5.21)$ \\
\hline \multirow[t]{2}{*}{ Tech emp pct } & + & $71.865^{* * *}$ & $63.491 * * *$ & $48.663 * * *$ & $48.445 * * *$ \\
\hline & & $(8.15)$ & $(7.58)$ & $(7.14)$ & $(8.33)$ \\
\hline \multirow[t]{2}{*}{ Tech indicator } & + & $11.500 * * *$ & $9.127 * * *$ & $8.806 * * *$ & $8.450 * * *$ \\
\hline & & $(6.54)$ & $(5.57)$ & $(5.73)$ & $(6.54)$ \\
\hline \multirow[t]{2}{*}{ Sales emp pct } & + & $54.229 * * *$ & $50.845^{* * *}$ & $42.635^{* * *}$ & $38.748 * * *$ \\
\hline & & $(7.51)$ & $(7.17)$ & $(5.89)$ & $(4.95)$ \\
\hline \multirow[t]{2}{*}{ Sales indicator } & + & -1.090 & -1.817 & -0.805 & -1.099 \\
\hline & & $(-0.68)$ & $(-1.19)$ & $(-0.53)$ & $(-0.81)$ \\
\hline \multirow[t]{2}{*}{ Retail emp pct } & - & $-29.989 * * *$ & $-23.245^{* * *}$ & $-24.050 * * *$ & $-23.838 * * *$ \\
\hline & & $(-11.59)$ & $(-8.86)$ & $(-9.30)$ & $(-6.79)$ \\
\hline \multirow[t]{2}{*}{ Retail indicator } & - & $-4.609 * * *$ & $-4.626 * * *$ & $-4.654 * * *$ & $-3.7438 * *$ \\
\hline & & $(-2.78)$ & $(-3.04)$ & $(-3.12)$ & $(-2.50)$ \\
\hline \multirow[t]{2}{*}{ Services emp pct } & - & $-26.946 * * *$ & $-27.099 * * *$ & $-27.684 * * *$ & $-16.690 * * *$ \\
\hline & & $(-7.59)$ & $(-8.32)$ & $(-8.37)$ & $(-4.53)$ \\
\hline \multirow[t]{2}{*}{ Services indicator } & - & $-5.760 * * *$ & $-3.018 * *$ & -2.063 & -1.684 \\
\hline & & $(-3.22)$ & $(-2.00)$ & $(-1.39)$ & $(-1.36)$ \\
\hline \multirow[t]{2}{*}{ Manufact emp pct } & - & -2.308 & -3.155 & -5.806 & $-11.852 * * *$ \\
\hline & & $(-0.52)$ & $(-0.81)$ & $(-1.57)$ & $(-3.01)$ \\
\hline \multirow[t]{2}{*}{ Manufact indicator } & - & -0.972 & 0.651 & -1.348 & $-2.594^{*}$ \\
\hline & & $(-0.54)$ & $(0.41)$ & $(-0.89)$ & $(-1.82)$ \\
\hline \multirow[t]{2}{*}{ Exec indicator } & + & $13.616^{* * *}$ & $13.458 * * *$ & $13.442 * * *$ & $13.307 * * *$ \\
\hline & & $(3.71)$ & $(3.66)$ & $(3.82)$ & $(3.86)$ \\
\hline \multirow[t]{2}{*}{ Supervisor pct } & + & $40.645^{* * *}$ & $36.220 * * *$ & $30.772 * * *$ & $33.067 * * *$ \\
\hline & & $(5.36)$ & $(5.85)$ & (5.64) & $(6.79)$ \\
\hline \multirow[t]{2}{*}{ Ind-region comp } & + & & $0.384 * * *$ & $0.288 * * *$ & $0.266^{* * *}$ \\
\hline & & & $(9.30)$ & $(8.65)$ & $(9.67)$ \\
\hline \multirow[t]{2}{*}{ College grad } & $+/-$ & & -0.030 & -0.034 & -0.023 \\
\hline & & & $(-0.71)$ & $(-0.89)$ & $(-0.73)$ \\
\hline \multirow[t]{2}{*}{ Right to work } & - & & -0.670 & $-0.987^{*}$ & $-0.956 * *$ \\
\hline & & & $(-0.99)$ & $(-1.75)$ & $(-2.05)$ \\
\hline \multirow[t]{2}{*}{ Ln assets } & + & & & $0.246^{* * *}$ & $0.306 * * *$ \\
\hline & & & & $(4.23)$ & $(4.12)$ \\
\hline \multirow[t]{2}{*}{ Ln age } & - & & & $-0.450 * * *$ & $-0.577 * * *$ \\
\hline & & & & $(-3.17)$ & $(-3.79)$ \\
\hline$R \& D /$ sales & + & & & $228.168 * * *$ & $199.097 * * *$ \\
\hline
\end{tabular}




\begin{tabular}{|c|c|c|c|c|c|}
\hline & & & & $(7.52)$ & $(6.67)$ \\
\hline Adj $R N O A$ & + & & & $\begin{array}{c}1.867 * * * \\
(2.98)\end{array}$ & $\begin{array}{c}2.615^{* * *} \\
(4.12)\end{array}$ \\
\hline RNOA Var & + & & & $\begin{array}{c}1.488^{* * *} \\
(4.71)\end{array}$ & $\begin{array}{c}1.133 * * * \\
(3.59)\end{array}$ \\
\hline Labor productivity & + & & & $\begin{array}{c}0.016^{* * *} \\
(5.86)\end{array}$ & $\begin{array}{c}0.012 * * * \\
(3.27)\end{array}$ \\
\hline Capital intensity & $+/-$ & & & $\begin{array}{c}-0.049 * * * \\
(-5.49)\end{array}$ & $\begin{array}{c}-0.0487 * * * \\
(-4.41)\end{array}$ \\
\hline Leverage & $+/-$ & & & $\begin{array}{l}-0.052 \\
(-0.21)\end{array}$ & $\begin{array}{l}-0.047 \\
(-0.22)\end{array}$ \\
\hline BTM & - & & & $\begin{array}{c}-2.988^{*} \\
(-1.75)\end{array}$ & $\begin{array}{c}-2.921 * * \\
(-2.14)\end{array}$ \\
\hline Ch rev & + & & & $\begin{array}{l}-3.796 \\
(-1.37)\end{array}$ & $\begin{array}{l}1.067 \\
(0.49)\end{array}$ \\
\hline Year fixed effects & & No & No & No & Yes \\
\hline Industry fixed effects & & No & No & No & Yes \\
\hline Observations & & 104,748 & 104,748 & 104,748 & 104,748 \\
\hline Firms & & 931 & 931 & 931 & 931 \\
\hline Adj. $R^{2}$ & & $52.5 \%$ & $55.0 \%$ & $58.1 \%$ & $61.1 \%$ \\
\hline
\end{tabular}


Panel B: CEO compensation model

\begin{tabular}{|c|c|c|}
\hline Variable & $\begin{array}{l}\text { predicted } \\
\text { sign }\end{array}$ & CEO pay \\
\hline$R O A$ & + & $\begin{array}{c}3,953.82 * * * \\
(4.66)\end{array}$ \\
\hline ROA var & + & $\begin{array}{c}5,916.10 * * * \\
(5.14)\end{array}$ \\
\hline $\operatorname{Ret}_{t}$ & + & $\begin{array}{c}166.021 \\
(1.09)\end{array}$ \\
\hline Ret var & + & $\begin{array}{c}5,916.10^{* * *} \\
(5.14)\end{array}$ \\
\hline $\operatorname{Ret}_{t-1}$ & + & $\begin{array}{c}639.009 * * * \\
(4.45)\end{array}$ \\
\hline Ln CEO tenure & + & $\begin{array}{c}352.363^{* * *} \\
(6.03)\end{array}$ \\
\hline Ln CEO age & + & $\begin{array}{c}-766.349 * \\
(-1.74)\end{array}$ \\
\hline Outside CEO & + & $\begin{array}{c}318.595 * * * \\
(2.90)\end{array}$ \\
\hline Loss & - & $\begin{array}{c}-15.754 \\
(-0.08)\end{array}$ \\
\hline Ln assets & + & $\begin{array}{c}2,413.50 * * * \\
(64.91)\end{array}$ \\
\hline$B T M$ & - & $\begin{array}{c}1,638.02 * * * \\
(9.96)\end{array}$ \\
\hline Leverage & $+/-$ & $\begin{array}{l}-22.267 \\
(-0.63)\end{array}$ \\
\hline Year fixed effects & & Yes \\
\hline Industry fixed effects & & Yes \\
\hline Observations & & 5,082 \\
\hline Firms & & 931 \\
\hline Adj. R2 & & $56.3 \%$ \\
\hline
\end{tabular}

Table 5 presents the results of the regression models used to measure explained employee and CEO compensation. Panel A reports the results of regressing the establishment, macroeconomic, and firm variables on mean establishmentlevel employee compensation. Firm-level variables are measured in period $\mathrm{t}-1$ to better capture their impact on employee compensation, which is measured when it is paid, not when it is earned. Panel B reports the results of regressing firm-level variables on CEO total compensation (CEO pay). All variables are defined in the Appendix. Continuous variables are winsorized at $1 \%$ and $99 \%$. Robust standard errors are clustered at the firm level. $t$ statistics are reported in parentheses. ${ }^{*}, * *$, and $* * *$ indicate significance at the $10 \%, 5 \%$, and $1 \%$ confidence level, respectively. 
Table 6: Pay ratios and firm-level descriptive statistics

Panel A: Pay ratios and firm-level characteristics: descriptive statistics

\begin{tabular}{lcccccc} 
Variable & $N$ & Mean & $\begin{array}{c}\text { Standard } \\
\text { deviation }\end{array}$ & Q1 & Median & $Q 3$ \\
\hline SPR & 5,082 & 101.55 & 135.95 & 24.67 & 55.11 & 123.36 \\
EPR & 5,082 & 72.72 & 131.19 & 18.01 & 55.73 & 108.57 \\
UPR & 5,082 & 23.29 & 138.36 & -18.76 & 7.040 & 38.88 \\
Adj RNOA & 5,082 & 0.015 & 0.22 & -0.018 & 0.011 & 0.056 \\
Assets & 5,082 & $15,424.15$ & $98,724.17$ & 905.88 & $2,771.52$ & $8,224.29$ \\
BTM & 5,082 & 0.526 & 0.364 & 0.287 & 0.452 & 0.684 \\
Leverage & 5,082 & 0.678 & 1.447 & 0.119 & 0.439 & 0.887 \\
Labor productivity & 5,082 & 441.76 & 512.28 & 197.57 & 293.63 & 476.3 \\
Capital intensity & 5,082 & 48.59 & 52.714 & 15.87 & 30.092 & 51.34 \\
Age & 5,082 & 29.46 & 19.53 & 15 & 23 & 39 \\
CEO pay & 5,082 & $5,814.28$ & $5,131.14$ & $2,051.48$ & $4,206.10$ & $7,700.07$ \\
Emp pct & 5,082 & 0.4432 & 0.9770 & 0.1402 & 0.3141 & 0.5739
\end{tabular}




\section{Panel B: Correlation matrix}

\begin{tabular}{|c|c|c|c|c|c|c|c|c|c|c|c|c|c|}
\hline & $S P R$ & $E P R$ & $U P R$ & Mean comp & CEO pay & Ln assets & Adj RNOA & BHAR & BTM & Leverage & Labor productivity & Capital intensity & Ln age \\
\hline$S P R$ & & $0.5053^{*}$ & $0.4458^{*}$ & $-0.5305^{*}$ & 0.77318 & $0.4993 *$ & $0.0998^{*}$ & -0.0093 & $-0.1508 *$ & $0.1768^{*}$ & $-0.1093 *$ & -0.0048 & $0.2449 *$ \\
\hline$E P R$ & $0.6579^{*}$ & & $-0.2432 *$ & $-0.1657^{*}$ & $0.4864^{*}$ & $0.4235^{*}$ & $0.0459^{*}$ & 0.0263 & $0.1299 *$ & $-0.2457^{*}$ & $0.0700^{*}$ & $0.0451^{*}$ & $-0.1983 *$ \\
\hline$U P R$ & $0.5335^{*}$ & $-0.2603^{*}$ & & $-0.3087^{*}$ & $0.0976^{*}$ & $0.0448^{*}$ & $-0.0304 *$ & $-0.0324^{*}$ & 0.0000 & $0.1971 *$ & $0.0737^{*}$ & $-0.1075^{*}$ & $0.0277^{*}$ \\
\hline Mean comp & $-0.3355^{*}$ & $-0.1090 *$ & $-0.1809^{*}$ & & $0.0629 *$ & $0.0386^{*}$ & $0.0794 *$ & -0.0171 & $-0.0594 *$ & -0.0244 & $0.4469^{*}$ & $-0.1066^{*}$ & -0.0213 \\
\hline CEO pay & $0.6255^{*}$ & $0.2604 *$ & $0.0568^{*}$ & $0.0466^{*}$ & & $0.6615^{*}$ & $0.1705^{*}$ & -0.0242 & $0.2178^{*}$ & $0.2180 *$ & $0.2013^{*}$ & $-0.0928^{*}$ & $0.2917^{*}$ \\
\hline Ln assets & $0.3448^{*}$ & $0.1847^{*}$ & $0.0340 *$ & $0.0960 *$ & $0.6325^{*}$ & & $0.0536^{*}$ & 0.0139 & 0.0259 & $0.4201 *$ & $0.3220^{*}$ & $-0.1693^{*}$ & $0.3835^{*}$ \\
\hline Adj $R N O A$ & $0.0522 *$ & $0.0785^{*}$ & $-0.0896^{*}$ & $-0.0874 *$ & $0.0930^{*}$ & $0.0345^{*}$ & & $-0.0834^{*}$ & $-0.3883 *$ & $-0.1843 *$ & $0.0276^{*}$ & 0.0205 & 0.0267 \\
\hline$B H A R$ & 0.0237 & 0.0262 & $-0.0318^{*}$ & -0.0155 & 0.0102 & 0.0187 & $-0.0327^{*}$ & & $0.0650^{*}$ & 0.0080 & $-0.0351 *$ & 0.0123 & 0.0065 \\
\hline$B T M$ & $-0.1331 *$ & 0.0086 & 0.0096 & 0.0088 & $0.1805^{*}$ & $0.0666^{*}$ & $-0.2003 *$ & 0.0174 & & $0.0388^{*}$ & 0.0145 & $0.0556^{*}$ & 0.0075 \\
\hline Leverage & $0.0923^{*}$ & $-0.0960 *$ & $0.0817^{*}$ & $0.0833^{*}$ & $0.0823^{*}$ & $0.2014^{*}$ & $-0.0461 *$ & -0.0043 & 0.005 & & $0.1518^{*}$ & $-0.1588^{*}$ & $0.1812 *$ \\
\hline Labor productivity & $-0.0356^{*}$ & $-0.0338 *$ & $0.0491^{*}$ & $0.2698 *$ & $0.1799 *$ & $0.1799 *$ & $0.2573 *$ & $-0.0378^{*}$ & $0.0731^{*}$ & 0.0172 & & $-0.0750 *$ & $0.0965^{*}$ \\
\hline Capital intensity & -0.0247 & $0.0357^{*}$ & $-0.0355^{*}$ & $-0.0705^{*}$ & $-0.0705^{*}$ & $-0.0636^{*}$ & $-0.0929 *$ & 0.0006 & $0.1118^{*}$ & $-0.0544^{*}$ & $0.1235^{*}$ & & -0.0176 \\
\hline Ln age & $0.1374 *$ & $-0.0865^{*}$ & $0.0438^{*}$ & $-0.0439 *$ & $-0.0439 *$ & $0.2981 *$ & $0.3915^{*}$ & 0.0167 & -0.0177 & $0.0639 *$ & $0.0454^{*}$ & $-0.0666^{*}$ & \\
\hline
\end{tabular}

Table 6 presents the descriptive statistics for the pay ratios and the other firm-level variables of interest. SPR (Simple Pay Ratio) is calculated as CEO compensation/mean employee compensation at the firm-level. EPR (Economic Pay Ratio) is calculated as CEO explained compensation/mean employee explained compensation, where explained compensation is calculated using Equation (1) for mean employee compensation and Equation (2) for CEO compensation. UPR (Unexplained Pay Ratio) is equal to SPR - EPR. Panel A reports general descriptive statistics. Panel B reports Pearson (Spearman) correlations below (above) the diagonal, with * indicating significance at the 5\% confidence level. All variables are defined in the Appendix. Continuous variables are winsorized at $1 \%$ and $99 \%$. 
Table 7: Validating $\operatorname{Ln} U P R$ (Unexplained Pay Ratio): association with proxies for employee satisfaction

\begin{tabular}{|c|c|c|c|c|c|c|}
\hline \multirow[b]{2}{*}{ Variable } & \multicolumn{2}{|c|}{ Fortune } & \multicolumn{2}{|c|}{ JUST fair pay } & \multicolumn{2}{|c|}{ Turnover } \\
\hline & (1) & $(2)$ & (3) & (4) & (5) & (6) \\
\hline \multirow[t]{2}{*}{$\operatorname{Ln} U P R$} & $-0.0109 *$ & $-0.0115^{*}$ & $-0.0363 *$ & $-0.0399 *$ & 0.0003 & $0.0004^{*}$ \\
\hline & $(-1.74)$ & $(-1.76)$ & $(-1.79)$ & $(-1.69)$ & $(1.60)$ & $(1.67)$ \\
\hline \multirow[t]{2}{*}{ Adj $R O A$} & & $2.7187 * * *$ & & $4.3060 * *$ & & $-0.1603^{* * *}$ \\
\hline & & $(4.07)$ & & $(2.05)$ & & $(-6.59)$ \\
\hline \multirow[t]{2}{*}{ Ln assets } & & $0.6392 * * *$ & & $-0.8695 * * *$ & & -0.0046 \\
\hline & & $(10.48)$ & & $(-6.27)$ & & $(-0.77)$ \\
\hline \multirow[t]{2}{*}{$B T M$} & & $-2.4853 * * *$ & & -0.1742 & & $0.0668 * * *$ \\
\hline & & $(-6.54)$ & & $(-0.31)$ & & $(9.32)$ \\
\hline \multirow[t]{2}{*}{ Leverage } & & $-0.1161 * *$ & & -0.0861 & & 0.0013 \\
\hline & & $(-2.53)$ & & $(-0.78)$ & & $(1.03)$ \\
\hline \multirow[t]{2}{*}{ Labor productivity } & & -0.0035 & & $0.1926 * * *$ & & $-0.0025 * *$ \\
\hline & & $(-0.19)$ & & $(4.68)$ & & $(-2.25)$ \\
\hline \multirow[t]{2}{*}{ Capital intensity } & & $-1.6833 * * *$ & & 0.2640 & & -0.0033 \\
\hline & & $(-4.11)$ & & $(0.71)$ & & $(-0.55)$ \\
\hline \multirow[t]{2}{*}{ Ln age } & & $-0.7758 * * *$ & & $-0.4941 *$ & & 0.0126 \\
\hline & & $(-5.55)$ & & $(-1.88)$ & & $(0.57)$ \\
\hline Year fixed effects & No & No & Yes & Yes & Yes & Yes \\
\hline Industry fixed effects & No & No & Yes & Yes & No & No \\
\hline Firm fixed effects & No & No & No & No & Yes & Yes \\
\hline Observations & 5,082 & 5,082 & 2,335 & 2,335 & 4,921 & 4,921 \\
\hline Firms & 931 & 931 & 375 & 375 & 918 & 918 \\
\hline Obs, Fortune $=1$ & 361 & 361 & & & & \\
\hline Adj. R2 & $0.99 \%$ & $17.9 \%$ & $10.1 \%$ & $13.6 \%$ & $35.3 \%$ & $37.9 \%$ \\
\hline
\end{tabular}

Table 7 reports the results of regressing firm-level measures of employee satisfaction on the natural log of the Unexplained Pay Ratio (Ln UPR) and control variables. UPR is equal to the Unexplained Pay Ratio as defined above. The dependent variable in Columns (1)-(2) is Fortune, an indicator equal to 1 if a firm was listed in Fortune's "100 Best Places to Work" list in that year. The dependent variable in Columns (3)-(4) is Just fair pay, the firm-level average of four variables related to employee compensation (fair pay, pay discrimination, paying a living wage, and non-executive pay compared to CEO pay), calculated by the not-for-profit organization JUST Capital using several data sources. The dependent variable in Columns (5)-(6) is Turnover, equal to the number of cancelled options in year $\mathrm{t}+1$ divided by the number of outstanding options in year $\mathrm{t}$, as defined by Carter and Lynch (2004). All variables are defined in the Appendix. Continuous variables are winsorized at $1 \%$ and $99 \%$. Robust standard errors are clustered at the firm level. $t$ statistics are reported in parentheses. *, ${ }^{* *}$, and ${ }^{* * *}$ indicate significance at the $10 \%, 5 \%$, and $1 \%$ confidence level, respectively. 
Table 8: Pay ratios and firm performance

Panel A: The pay ratios and year-ahead operating performance

\begin{tabular}{|c|c|c|c|c|c|c|c|c|}
\hline \multirow[b]{2}{*}{ Variable } & \multicolumn{8}{|c|}{$\operatorname{Adj} R_{N O A_{t+1}}$} \\
\hline & (1) & $(2)$ & (3) & (4) & (5) & $(6)$ & (7) & (8) \\
\hline \multirow[t]{2}{*}{ Ln $S P R$} & 0.0011 & & & & 0.0006 & & & \\
\hline & $(1.44)$ & & & & $(0.78)$ & & & \\
\hline \multirow[t]{2}{*}{$L n E P R$} & & $0.0009 * * *$ & & $0.0014 * *$ & & $0.0010 * * *$ & & $0.0018 * *$ \\
\hline & & $(2.73)$ & & $(2.18)$ & & $(2.96)$ & & $(2.23)$ \\
\hline \multirow[t]{2}{*}{$\operatorname{Ln} U P R$} & & & $-0.0013 * *$ & -0.0009 & & & $-0.0013 * *$ & $-0.0013 *$ \\
\hline & & & $(-2.43)$ & $(-1.56)$ & & & $(-2.54)$ & $(-1.75)$ \\
\hline \multirow[t]{2}{*}{$\operatorname{Adj} \mathrm{RNOA}_{t}$} & & & & & -0.0250 & -0.0263 & -0.0262 & -0.0260 \\
\hline & & & & & $(-1.41)$ & $(-1.49)$ & $(-1.49)$ & $(-1.47)$ \\
\hline \multirow[t]{2}{*}{ Ln assets } & & & & & $-0.0716^{* * *}$ & $-0.0695 * * *$ & $-0.0700 * * *$ & $-0.0693 * * *$ \\
\hline & & & & & $(-5.37)$ & $(-5.23)$ & $(-5.27)$ & $(-5.22)$ \\
\hline \multirow[t]{2}{*}{ BTM } & & & & & $-0.1776 * * *$ & $-0.1807 * * *$ & $-0.1798 * * *$ & $-0.1812 * * *$ \\
\hline & & & & & $(-11.07)$ & $(-11.31)$ & $(-11.26)$ & $(-11.33)$ \\
\hline \multirow[t]{2}{*}{ Leverage } & & & & & 0.0001 & 0.0001 & 0.0001 & 0.0001 \\
\hline & & & & & $(0.03)$ & $(0.05)$ & $(0.04)$ & $(0.04)$ \\
\hline \multirow[t]{2}{*}{ Labor productivity } & & & & & $0.0036^{*}$ & $0.0036^{*}$ & $0.0036^{*}$ & $0.0037^{*}$ \\
\hline & & & & & $(1.68)$ & $(1.68)$ & $(1.67)$ & $(1.70)$ \\
\hline \multirow[t]{2}{*}{ Capital intensity } & & & & & 0.0052 & 0.0048 & 0.0051 & 0.0046 \\
\hline & & & & & $(0.39)$ & $(0.36)$ & $(0.38)$ & $(0.35)$ \\
\hline \multirow[t]{2}{*}{ Ln age } & & & & & 0.0156 & 0.0187 & 0.0180 & 0.0191 \\
\hline & & & & & $(0.33)$ & $(0.40)$ & $(0.38)$ & $(0.41)$ \\
\hline Year fixed effects & Yes & Yes & Yes & Yes & Yes & Yes & Yes & Yes \\
\hline Firm fixed effects & Yes & Yes & Yes & Yes & Yes & Yes & Yes & Yes \\
\hline Observations & 5,082 & 5,082 & 5,082 & 5,082 & 5,082 & 5,082 & 5,082 & 5,082 \\
\hline Firms & 931 & 931 & 931 & 931 & 931 & 931 & 931 & 931 \\
\hline Adj. R2 & $28.5 \%$ & $28.6 \%$ & $28.6 \%$ & $28.7 \%$ & $31.5 \%$ & $31.7 \%$ & $31.6 \%$ & $31.8 \%$ \\
\hline
\end{tabular}


Panel B: Industry-adjusted pay ratios and year-ahead operating performance

Adj $R_{N O A_{t+1}}$

\begin{tabular}{lcccc}
\cline { 2 - 5 } Variable & $\mathbf{( 1 )}$ & $\mathbf{( 2 )}$ & $\mathbf{( 3 )}$ & $\mathbf{( 4 )}$ \\
\hline Industry-adjusted Ln SPR & -0.0039 & & & \\
Industry-adjusted Ln EPR & $(-0.57)$ & & & $0.0022^{* *}$ \\
& & $0.0011^{* * *}$ & & $(2.07)$ \\
Industry-adjusted Ln UPR & & $(3.35)$ & $-0.0015^{* * *}$ & $-0.0017^{* *}$ \\
& & & $(-2.84)$ & $(-2.44)$ \\
Adj RNOA & & & -0.0264 & -0.0261 \\
& -0.0240 & -0.0265 & $(-1.49)$ & $(-1.48)$ \\
Ln assets & $(-1.36)$ & $(-1.50)$ & $-0.069)^{* * *}$ & $-0.0691^{* * *}$ \\
& $-0.0704^{* * *}$ & $-0.0694^{* * *}$ & -0.0690 \\
BTM & $(-5.28)$ & $(-5.22)$ & $(-5.26)$ & $(-5.20)$ \\
& $-0.1797^{* * *}$ & $-0.1813^{* * *}$ & $-0.1802^{* * *}$ & $-0.1820^{* * *}$ \\
Leverage & $(-11.20)$ & $(-11.35)$ & $(-11.28)$ & $(-11.38)$ \\
& 0.0001 & 0.0001 & 0.0001 & 0.0002 \\
Labor productivity & $(0.03)$ & $(0.04)$ & $(0.03)$ & $(0.05)$ \\
& $0.0038^{*}$ & $0.0036^{*}$ & $0.0036^{*}$ & $0.0036^{*}$ \\
Capital intensity & $(1.75)$ & $(1.68)$ & $(1.67)$ & $(1.70)$ \\
& 0.0050 & 0.0048 & 0.0050 & 0.0047 \\
Ln age & $(0.38)$ & $(0.36)$ & $(0.38)$ & $(0.35)$ \\
& 0.0171 & 0.0193 & 0.0183 & 0.0197 \\
& $(0.36)$ & $(0.41)$ & $(0.39)$ & $(0.42)$ \\
\hline Year fixed effects & & & & \\
Firm fixed effects & Yes & Yes & Yes & Yes \\
Observations & Yes & Yes & Yes & Yes \\
Firms & 5,082 & 5,082 & 5,082 & 5,082 \\
Adj. R2 & 931 & 931 & 931 & 931 \\
& $31.5 \%$ & $31.7 \%$ & $31.7 \%$ & $31.8 \%$ \\
\hline
\end{tabular}

Table 8 reports an analysis of the relation between firm performance and pay ratios. In all panels, performance is measured as Adj $R N O A_{t+1}$. Ln SPR, $L n E P R$, and $L n U P R$ are equal to the natural logs of the pay ratios as defined above. Panel A examines the relation between $A d j R N O A$ and the pay ratios. Panel B reports the results of the relation between Adj RNOA and industry-adjusted pay ratios, where the adjusted ratios are equal to the ratio - the median industry-year ratio (industry is defined by two-digit SIC code). All variables are defined in the Appendix. Continuous variables are winsorized at $1 \%$ and $99 \%$. Robust standard errors are clustered at the firm level. $t$ statistics are reported in parentheses. ${ }^{*}, *$, and $* * *$ indicate significance at the $10 \%, 5 \%$, and $1 \%$ confidence level, respectively. 
Table 9: Examining the relation between the numerator and denominator of the unexplained pay ratio

Panel A: How Excess CEO pay and Excess mean pay create the UPR

\begin{tabular}{lccc} 
Case & $\begin{array}{c}\text { Sign of Excess } \\
\text { CEO pay }\end{array}$ & $\begin{array}{c}\text { Sign of Excess } \\
\text { mean pay }\end{array}$ & $\begin{array}{c}\text { Sign of } \\
\text { UPR }\end{array}$ \\
\hline Case 1 & - & - & + \\
Case 2 & - & - & - \\
Case 3 & + & - & + \\
Case 4 & - & + & - \\
Case 5 & + & + & - \\
Case 6 & + & + & +
\end{tabular}


Panel B: The relation between different types of UPR and performance

\begin{tabular}{|c|c|c|c|}
\hline \multirow{3}{*}{ Variable } & & \multicolumn{2}{|c|}{$\operatorname{Adj} R N O A_{t+1}$} \\
\hline & \multirow[b]{2}{*}{$\mathrm{N}$} & Case indicator & Case indicator $*$ Ln UPR \\
\hline & & (1) & (2) \\
\hline \multirow[t]{2}{*}{ Case 1} & 829 & -0.0220 & -0.0015 \\
\hline & & $(-0.88)$ & $(-1.27)$ \\
\hline \multirow[t]{2}{*}{ Case 2} & 811 & $-0.0423 *$ & $-0.0038 *$ \\
\hline & & $(-1.71)$ & $(-1.92)$ \\
\hline \multirow[t]{2}{*}{ Case 3} & 1,212 & $-0.0506^{* *}$ & $-0.0049 * * *$ \\
\hline & & $(-2.08)$ & $(-3.52)$ \\
\hline \multirow[t]{2}{*}{ Case 4} & 1,032 & -0.0323 & $0.0048 * *$ \\
\hline & & $(-1.36)$ & $(2.04)$ \\
\hline \multirow{2}{*}{ Case 5} & 501 & -0.0428 & -0.0038 \\
\hline & & $(-1.63)$ & $(-1.38)$ \\
\hline \multirow[t]{2}{*}{ Case 6} & 697 & 0.0060 & -0.0000 \\
\hline & & $(1.29)$ & $(-0.05)$ \\
\hline \multirow[t]{2}{*}{$\operatorname{Adj} R N O A_{t}$} & & -0.0242 & -0.0290 \\
\hline & & $(-1.37)$ & $(-1.65)$ \\
\hline \multirow{2}{*}{ Ln assets } & & $-0.0725 * * *$ & $-0.0671 * * *$ \\
\hline & & $(-5.41)$ & $(-5.05)$ \\
\hline \multirow[t]{2}{*}{$B T M$} & & $-0.1783 * * *$ & $-0.1824 * * *$ \\
\hline & & $(-11.07)$ & $(-11.43)$ \\
\hline \multirow[t]{2}{*}{ Leverage } & & 0.0000 & 0.0000 \\
\hline & & $(0.00)$ & $(0.00)$ \\
\hline \multirow[t]{2}{*}{ Labor productivity } & & $0.0040^{*}$ & $0.0039 *$ \\
\hline & & $(1.86)$ & $(1.77)$ \\
\hline \multirow[t]{2}{*}{ Capital intensity } & & 0.0043 & 0.0023 \\
\hline & & $(0.33)$ & $(0.18)$ \\
\hline \multirow[t]{2}{*}{ Ln age } & & 0.0176 & 0.0112 \\
\hline & & $(0.37)$ & $(0.24)$ \\
\hline Year fixed effects & & Yes & Yes \\
\hline Firm fixed effects & & Yes & Yes \\
\hline Observations & & 5,082 & 5,082 \\
\hline Number of firms & & 931 & 931 \\
\hline Adj. R2 & & $31.6 \%$ & $32.0 \%$ \\
\hline
\end{tabular}

Table 9 reports the results of regressions of the pay-performance relation based on the differing compensations of the $\mathrm{CEO}$ and the mean employee. Performance is measured as Adj $R N O A_{t+1}$. Ln UPR is equal to the natural $\log$ of the Unexplained Pay Ratio as defined above. Panel A explains how the signs of Excess CEO pay and Excess mean pay create the sign of UPR. Excess CEO pay is total CEO pay - explained CEO pay, where explained pay is calculated in Equation (2). Excess mean pay is total Mean pay - explained mean pay, where explained pay is calculated in Equation (1). Panel B examines the relation between each case from Panel A and Adj $R N O A_{t+1}$. Column (1) regresses an indicator for each case on performance. The independent variables of interest in Column (2) are interactions between the case indicators and $L n U P R$. All variables are defined in the Appendix. Continuous variables are winsorized at $1 \%$ and $99 \%$. Robust standard errors are clustered at the firm level. t statistics are reported in parentheses. $*$, **, and *** indicate significance at the $10 \%, 5 \%$, and $1 \%$ confidence level, respectively. 
Table 10: The impact of corporate governance on the $L n U P R$-performance relation

\begin{tabular}{|c|c|c|}
\hline \multirow[b]{2}{*}{ Variable } & \multicolumn{2}{|c|}{ Adj $R N O A_{t+1}$} \\
\hline & (1) & (2) \\
\hline Ln UPR & $\begin{array}{c}-0.0017 * * * \\
(-2.85)\end{array}$ & $\begin{array}{l}-0.0009 \\
(-1.30)\end{array}$ \\
\hline High Eindex & $\begin{array}{c}0.0084 \\
(0.54)\end{array}$ & \\
\hline Ln UPR * High Eindex & $\begin{array}{c}-0.0036^{* * *} \\
(-3.32)\end{array}$ & \\
\hline Low InstOwn & & $\begin{array}{c}-0.0117 \\
(-1.06)\end{array}$ \\
\hline$U P R *$ Low InstOwn & & $\begin{array}{l}-0.0010 \\
(-1.39)\end{array}$ \\
\hline $\operatorname{Adj} R N O A_{t}$ & $\begin{array}{c}-0.0901 * * * \\
(-4.43)\end{array}$ & $\begin{array}{c}-0.0211 \\
(-1.18)\end{array}$ \\
\hline Ln assets & $\begin{array}{c}-0.1446^{* * *} \\
(-8.14)\end{array}$ & $\begin{array}{c}-0.0744 * * * \\
(-5.23)\end{array}$ \\
\hline BTM & $\begin{array}{c}-0.1741 * * * \\
(-8.94)\end{array}$ & $\begin{array}{c}-0.1773 * * * \\
(-10.83)\end{array}$ \\
\hline Leverage & $\begin{array}{l}0.0006 \\
(0.16)\end{array}$ & $\begin{array}{l}0.0004 \\
(0.13)\end{array}$ \\
\hline Labor productivity & $\begin{array}{l}0.0031 \\
(1.36)\end{array}$ & $\begin{array}{c}0.0039^{*} \\
(1.86)\end{array}$ \\
\hline Capital intensity & $\begin{array}{l}0.0115 \\
(0.78)\end{array}$ & $\begin{array}{c}0.0108 \\
(0.83)\end{array}$ \\
\hline Ln age & $\begin{array}{c}0.1583 * * \\
(2.55)\end{array}$ & $\begin{array}{c}0.0008 \\
(0.02)\end{array}$ \\
\hline Year fixed effects & Yes & Yes \\
\hline Firm fixed effects & Yes & Yes \\
\hline Observations & 3,754 & 4,820 \\
\hline Number of firms & 792 & 904 \\
\hline Adj. R2 & $29.0 \%$ & $31.6 \%$ \\
\hline
\end{tabular}

Table 10 examines how the relation between $L n U P R$ and performance varies between subgroups with differing levels of CEO power and monitoring. Performance is measured as $A d j R N O A_{t+1}$. $L n U P R$ is equal to the natural $\log$ of the Unexplained Pay Ratio as defined above. In Column (1), High Eindex is equal to 1 if the firm has an Entrenchment Index greater than 1, and 0 otherwise. In Column (2), Low InstOwn is equal to 1 if the percent of a firm's shares held by institutional investors is less than the median, and 0 otherwise. All variables are defined in the Appendix. Continuous variables are winsorized at $1 \%$ and $99 \%$. Robust standard errors are clustered at the firm level. t statistics are reported in parentheses. ${ }^{*},{ }^{*}$, and $* * *$ indicate significance at the $10 \%, 5 \%$, and $1 \%$ confidence level, respectively. 
Table 11: The impact of employee characteristics on the $L n U P R$-performance relation Panel A: Employee satisfaction and the Ln UPR-performance relation

\begin{tabular}{|c|c|c|}
\hline \multirow[b]{2}{*}{ Variable } & \multicolumn{2}{|c|}{$\operatorname{Adj} R N O A_{t+1}$} \\
\hline & (1) & (2) \\
\hline Ln UPR & $\begin{array}{c}0.0066^{* *} \\
(2.58)\end{array}$ & $\begin{array}{c}0.0005 \\
(0.71)\end{array}$ \\
\hline No Fortune & $\begin{array}{c}-0.0339 \\
(-0.87)\end{array}$ & \\
\hline$U P R *$ No Fortune & $\begin{array}{c}-0.0082^{* * * *} \\
(-3.16)\end{array}$ & \\
\hline Low Just fair pay & & $\begin{array}{c}-0.0024 \\
(-0.24)\end{array}$ \\
\hline UPR * Low Just fair pay & & $\begin{array}{c}-0.0049 * * * \\
(-4.46)\end{array}$ \\
\hline $\operatorname{Adj} \mathrm{RNOA}_{t}$ & $\begin{array}{c}-0.0271 \\
(-1.54)\end{array}$ & $\begin{array}{c}0.2995^{* * *} \\
(13.72)\end{array}$ \\
\hline Ln assets & $\begin{array}{c}-0.0707 * * * \\
(-5.32)\end{array}$ & $\begin{array}{l}0.0025 \\
(0.67)\end{array}$ \\
\hline BTM & $\begin{array}{c}-0.1795 * * * \\
(-11.25)\end{array}$ & $\begin{array}{c}-0.1322^{* * * *} \\
(-9.20)\end{array}$ \\
\hline Leverage & $\begin{array}{l}0.0001 \\
(0.04)\end{array}$ & $\begin{array}{c}0.0010 \\
(0.35)\end{array}$ \\
\hline Labor productivity & $\begin{array}{c}0.0036^{*} \\
(1.69)\end{array}$ & $\begin{array}{l}0.0006 \\
(0.51)\end{array}$ \\
\hline Capital intensity & $\begin{array}{l}0.0051 \\
(0.39)\end{array}$ & $\begin{array}{l}0.0029 \\
(0.25)\end{array}$ \\
\hline Ln age & $\begin{array}{l}0.0179 \\
(0.38)\end{array}$ & $\begin{array}{l}-0.0050 \\
(-0.71)\end{array}$ \\
\hline Year fixed effects & Yes & Yes \\
\hline Industry fixed effects & No & Yes \\
\hline Firm fixed effects & Yes & No \\
\hline Observations & 5,082 & 2,335 \\
\hline Firms & 931 & 375 \\
\hline Obs, Fortune $=1$ & 361 & \\
\hline Adj. R2 & $31.8 \%$ & $19.0 \%$ \\
\hline
\end{tabular}


Panel B: The labor market and the Ln UPR-performance relation

\begin{tabular}{|c|c|c|}
\hline \multirow[b]{2}{*}{ Variable } & \multicolumn{2}{|c|}{ Adj $R N O A_{t+1}$} \\
\hline & (1) & (2) \\
\hline Ln UPR & $\begin{array}{c}0.0003 \\
(0.34)\end{array}$ & $\begin{array}{c}0.0013 \\
(1.06)\end{array}$ \\
\hline High Turn & $\begin{array}{c}0.0159^{*} \\
(1.80)\end{array}$ & \\
\hline UPR * High Turn & $\begin{array}{c}-0.0023 * * * \\
(-2.94)\end{array}$ & \\
\hline High Lab Mark & & $\begin{array}{c}-0.0107 \\
(-0.53)\end{array}$ \\
\hline UPR * High LabMark & & $\begin{array}{c}-0.0036^{* *} \\
(-2.45)\end{array}$ \\
\hline $\operatorname{Adj} R N O A_{t}$ & $\begin{array}{c}-0.0317^{*} \\
(-1.77)\end{array}$ & $\begin{array}{c}-0.0517 * * \\
(-2.07)\end{array}$ \\
\hline Ln assets & $\begin{array}{c}-0.0640 * * * \\
(-4.68)\end{array}$ & $\begin{array}{c}-0.0374 * \\
(-1.87)\end{array}$ \\
\hline BTM & $\begin{array}{c}-0.1793 * * * \\
(-10.91)\end{array}$ & $\begin{array}{c}-0.1374 * * * \\
(-6.64)\end{array}$ \\
\hline Leverage & $\begin{array}{c}-0.0003 \\
(-0.10)\end{array}$ & $\begin{array}{c}0.0007 \\
(0.17)\end{array}$ \\
\hline Labor productivity & $\begin{array}{c}0.0042^{*} \\
(1.71)\end{array}$ & $\begin{array}{c}-0.0007 \\
(-0.28)\end{array}$ \\
\hline Capital intensity & $\begin{array}{l}0.0033 \\
(0.25)\end{array}$ & $\begin{array}{l}0.0150 \\
(1.00)\end{array}$ \\
\hline Ln age & $\begin{array}{l}0.0048 \\
(0.09)\end{array}$ & $\begin{array}{r}-0.0397 \\
(-0.58)\end{array}$ \\
\hline Year fixed effects & Yes & Yes \\
\hline Firm fixed effects & Yes & Yes \\
\hline Observations & 4,921 & 2,580 \\
\hline Number of firms & 918 & 511 \\
\hline Adj. R2 & $32.1 \%$ & $34.1 \%$ \\
\hline
\end{tabular}

Table 11 examines how the relation between $L n U P R$ and performance varies based on employee characteristics. Performance is measured as $A d j R N O A_{t+1}$. Ln UPR is equal to the natural log of the Unexplained Pay Ratio as defined above. Panel A examines how employee satisfaction influences the $L n U P R$-performance relation. In Column (1), No Fortune is an indicator equal to 1 if a firm was not listed in Fortune's "100 Best Places to Work" list in that year. In Column (2), Low Just fair pay is equal to 1 if the firm-level average of Just fair pay is below the median. Panel B examines how the labor market influences the Ln UPR-performance relation. In Column (1), High Turn is equal to 1 if Turnover is greater than the median, and 0 otherwise. In Column (2), High LabMark is equal to 1 if a firm is in an industry where Labor market tightness is greater than the median, and 0 otherwise. All variables are defined in the Appendix. Continuous variables are winsorized at 1\% and $99 \%$. Robust standard errors are clustered at the firm level. $t$ statistics are reported in parentheses. $* * *$, and $* * *$ indicate significance at the $10 \%$, $5 \%$, and $1 \%$ confidence level, respectively. 